\title{
UNDERSTANDING PACIFIC ISLAND WELL-BEING PERSPECTIVES THROUGH SAMOAN AND TONGAN MATERIAL CULTURAL ADAPTATIONS AND SPATIAL BEHAVIOUR IN AUCKLAND AND BRISBANE
}

\author{
Ruth Faleolo ${ }^{1}$
}

\begin{abstract}
The aim of this paper is to discuss the tangible links that exist between Pacific Island well-being perspectives and their material culture. We can gain a better understanding of Pacific Island well-being perspectives through the analysis of Samoan and Tongan material cultural adaptations and how people interact with these via spatial behaviour, as observed in Auckland and Brisbane. This paper analyses a collection of images that capture evidence of six different types of material cultural adaptations that infer on, and reference spatial behaviours. Preliminary findings have been drawn from a wider-scale research project conducted during 2015-2018, that has explored Pacific Island TransTasman migrants' perspectives of well-being. This inquiry process has revealed significant links between Pacific Island traditions and adaptations in Pacific diaspora contexts.
\end{abstract}

Keywords: diaspora; material culture; Pacific Island; Samoan; Tongan.

\section{INTRODUCTION}

The Pacific diaspora are dispersed peoples and communities from the Pacific Islands that are now living in significant collective populations in Australia, New Zealand, and the United States (Ka'ili 2017, 21, 52-53, 94; Scull 2004, 53-56). This paper is focused on the Pacific Island migrants from the island nations of Samoa and Tonga, who reside in Australia and New Zealand. More specifically, this paper aims to discuss the links between Samoan and Tongan diasporas' sense of well-being as it relates to Samoan and Tongan diasporic material culture in Auckland and Brisbane. 
There are contrasting views on whether migrants remain culturally whole and socially connected despite the distance travelled (Ka'ili 2017; Thomsen, Tavita, and Levi-Teu 2018). Mainstream diaspora theorists (Brettell 2003; Park 1997; Portes and Rumbaut 2001) suggest migrants become uprooted from their culture and disconnected from their people when they leave their homelands (Guo 2016; Mila-Schaaf 2010). However, Gershon (2007; 2012) suggests that Pacific Island family webs interconnect people from island homelands and diasporas, allowing for the continued exchange and circulation of cultural knowledge and resources (Gershon 2007, 474-475; 2012, 39-47). LilomaiavaDoktor $(2009,22)$ contributes further insights from her study of Samoan people's malaga (Samoan concept of migration) to New Zealand and the United States, concluding that:

[...] distance does not separate 'äiga [families], but only provides further interconnecting social pathways $[. .$.$] because social connec-$ tions constitute a significant part of people's identity and self-esteem. It is $[\ldots]$ social connections, rather than geographic boundaries that are central to Samoan conceptions of movement.

In response to this debate, I ask: Are Pacific Island migrants in Auckland and Brisbane disconnected from their Pacific homelands, or do we remain culturally and socially connected? I would suggest that an analysis of material culture will provide us with answers to this question. Furthermore, I propose material culture demonstrates the adaptability and persistence of Pacific Island cultural traditions, practices, and beliefs. Material cultural changes are not necessarily the loss of culture or a disconnection from its origins. Several scholars (Abbott 2013; Memmott 2011; Pye 1999; Schlereth 2001; Van der Grijp 2011) outline significant aspects of material culture that relate to this discussion: all argue in various ways that material culture can change; that it is a form of cultural expression; and that it allows for a redefining of identity. Thomas Schlereth $(2001,3827)$ defines material culture as:

that segment that has been purposely made or modified, consciously or unconsciously, by people according to culturally dictated plans. Material culture entails those artefacts that humankind creates to cope with the physical world, to regulate its social relations, to perform its work, to delight its fancy, and to create symbols of meaning.

According to Abbott (2013), material culture is a fundamental form of cultural expression that reflects the societal values and beliefs of the people and culture who produce and use the objects (Abbott 2013,3-4). Material culture is a cul- 
tural expression. Pye $(1999,153)$ states that 'all artefacts are the result of a series of mental and manual processes, each object represents the result of a series of mental and manual processes, each object represents the externalization of an inner template that is both personal and cultural'.

Van der Grijp (2011, 277) extends this understanding of internal/external notions of material culture by highlighting the freedom of cultural expression used by Tongan artists to reshape their contemporary Pacific Islander identity, and redefine the meanings behind their use of material culture through meaningful art. Similarly, Mallon (2010, 367-376) promotes the removal of 'limits' for how we think about the past and present in relation to Pacific material cultures that have been acquired, presented, and utilised in New Zealand. Memmott (2011,39-41, 50-51) discusses the categorical changes of culture and tradition when Pacific peoples reconstruct material culture from available local materials and artefacts. He suggests that Pacific architecture in places like New Zealand, is a form of cultural expression that is based on internal thought patterns. Pacific knowledge is embodied by material culture that is either transferred from the traditional homelands or created within diaspora contexts from locally sourced materials using traditional templates or traditional meanings. According to Memmott $(2011,50-51)$ material culture is influenced by an attitude or outlook that may be further moulded by interactions with other cultures, versions of agency, and power. In doing so, he also raised concerns about the perceived uncompromising changes of culture and tradition. Memmott (2011, 39) outlines two paradigms of tradition and culture: the first is a static [notion of tradition...] regarded as entities having an essence apart from any interpretation', and the second is a definition of culture and tradition that accepts 'changes will occur [...] particularly with the processes of inter-generational transmission and enculturation'. The latter concept is supported by Taouma's observations $(2002,137)$ in Auckland about the changing ideas and application of Samoan culture and tradition. Similarly, and in alignment with the voices of my informants, my discussion in this paper will embrace a nuanced definition of culture and tradition. My argument embraces the salience of both change and persistence in relation to the adaptation of material culture as this relates to the works I analyse here.

I argue that the significance of Samoan and Tongan material cultural adaptations and spatial behaviour I observed in Auckland and Brisbane, is that they are reflections of holistic well-being perspectives within these contexts. Spirituality, familial and cultural spheres are intrinsic to the holistic well-being of Samoan/Tongan individuals and collectives as observed in Auckland and Brisbane (Enari 2019; Faleolo 2019; Mafi 2018; Pope 2017). The material cultural 
adaptations observed include variations of materials, templates, and spatial behaviour. Here, 'spatial behaviour' refers to the ways Samoan/Tongan people use spaces to create settings within diaspora contexts to use Samoan/Tongan material culture, or how Pacific Island material culture has redefined spaces (both private/public) and therefore influenced sociocultural behaviours within these spaces. In this discussion, six different types of material cultural adaptations and spatial behaviours will be considered.

The aim of this paper is to discuss the significant links that exist between Pacific Island well-being perspectives and Pacific Island material culture. These preliminary findings have been drawn from a wider-scale research project that has explored Pacific Island Trans-Tasman migrants' perspectives of well-being during 2015-2018. The following sections outline relevant background and research methods used to produce the findings presented here.

\section{BACKGROUND}

\section{Pacific Diaspora: Trans-Tasman migrants}

The phrase 'Pacific Island Trans-Tasman migration' refers to the movement of Samoan and Tongan diaspora across the Tasman Sea, between Auckland and Brisbane. This movement is a part of a greater Trans-Tasman migration flow of New Zealanders to Australia and vice versa (Green, Power, and Jang 2008, 35; Poot 2010, 319-320). The circulatory movements of Australian-based Pacific Islanders and New Zealand-based Pacific Islanders between Australia and New Zealand are a result of families and communities being established on both sides of the Tasman Sea in Australia and New Zealand. This fact is well-recorded by other Pacific scholars (Ka'ili 2017, 76-80; Lilomaiava-Doktor 2009, 10; Va'a 2001, 81).

Forty of the Pacific Island Trans-Tasman migrants in the cohort from my research are multi-diaspora migrants, having migrated and settled more than once in several diasporic settings. ${ }^{2}$ Pacific diaspora movements are continual and circular in some familial and communal groups, with many individuals and groups visiting their island homelands on an annual basis. Pacific people travel often to attend important family events, community meetings, and church or village-based events in their island homelands, or in other diaspora locations across Australia, New Zealand, and the United States of America (Addo 2015; Barcham, Scheyvens, and Overton 2009, 329-333; Bedford 2007, 2-4; 2009, 37-40; Poot 2010, 319-320). 


\section{Tradition: Anga faka-Tonga and fa'a-Sāmoa}

Anga faka-Tonga (the 'Tongan way of life') and fa'a-Sämoa (the 'Samoan way of life') are life institutions and socially accepted norms that support cultural identity and traditions in diaspora contexts (Faleolo 2012, 8; Lilomaiava-Doktor 2009, 7). I assert that the concepts of 'tradition' are subjectively defined by Pacific Islanders who use the concepts of anga faka-Tonga and fa'a-Sämoa within a diaspora context (Mila-Schaaf 2010, 246-247, 260-262). Therefore, my use of the term 'traditional' in my discussion of material cultural adaptations is done so with the understanding that this concept is highly contested. Nevertheless, core 'values' of respect for God and love for family are aspects of both anga faka-Tonga and fa'a-Sämoa generally accepted by Pacific Island diaspora as 'traditional'.

Identity is subjective, fluid and up to the individual. Nonetheless Samoan and Tongan diaspora select for themselves subjective identities, according to cultural protocols. There are central social principles which Tongan and Samoan diaspora adhere to that are fundamental to the Tongan and Samoan ways of life. Tongan cultural theorist Ka'ili (2017) states that Tongan values are fundamental to the Tongan cultural way of being, in particular tauhi $v \bar{a}$ (maintaining relationships) is central to anga faka-Tonga (Ka'ili 2017, 30-31). Gershon (2012, 56-57) and Ioane (2017) explain that fa' $a$-Sämoa is a way of thinking, and is known as the 'Samoan perspective' or 'Samoan worldview', whereby Samoans pride themselves on their relationships to their family, village, and community (Ioane 2017, 38).

METHODS

Recruitment for wider-scale study

This paper presents preliminary findings drawn from a wider-scale research project that has explored Pacific Island migrants' (of Samoan and Tongan descent) perceptions and experiences of well-being during 2015-2018. Key informants from Samoan and Tongan groups were identified from a range of settings: within their 'äiga, ${ }^{3} k \bar{a} i n g a,{ }^{4}$ or fämili, ${ }^{5}$ and from public leadership contexts, including church leaders, other community group leaders, and pastoral and academic leaders in local schools. Key informants helped to initiate the snowball recruitment of other informants that were interviewed. 


\section{Talanoa - a culturally responsive approach}

To capture Pacific Island voices on their own experiences and perceptions of well-being within peoples' lived environments in Auckland and Brisbane, it was critical to employ a culturally responsive methodology. The two-way interviewing process of talanoa (a Tongan method of conversation that embraces cultural protocols of knowledge-sharing) is a culturally responsive way of interviewing in Pacific Island contexts (Vaioleti 2006, 22-26). Talanoa is a 'conversation, a talk, and an exchange of ideas, be it formal or informal' (Vaioleti 2016,1) without a rigid framework. According to Havea (2010, 14), talanoa 'opens sacred texts and traditional values [...] to all participants who engage one another'. Thus, talanoa has been widely accepted as an approach for gathering in-depth qualitative data across a range of Pacific academic circles (Fa'avae, Jones, and Manu'atu 2016, 141-143; Halapua 2007, 3; Otsuka 2006, 2-5; Prescott 2008, 128).

In June to August 2015, forty initial interviews ${ }^{6}$ with Pacific Island Trans-Tasman migrants were carried out using two qualitative approaches: traditional face-toface talanoa and e-talanoa, ${ }^{7}$ a unique form of talanoa using online forums that allowed for conversations across different time-zones and geographies. What I term e-talanoa was in direct response to the request of the informants. This methodological development provided the flexibility and ease for informants to participate in interviews around their schedules. The e-talanoa interviews occurred over dispersed hours, or several days via online private messenger dialogue or email 'volley' conversation. ${ }^{8}$

\section{Participant-observation}

Alongside the interviews, participant-observation provided a rich collection of photographs and field notes. Participant-observation is a method of data collection that allowed me as the researcher to actively observe and to participate in the daily activities of those under study (Singleton and Straits 2010, 365). Participant-observations in Auckland and Brisbane during 2015-2018 took place at a variety of diaspora settings, including places of dwelling, religious and non-religious gatherings, and family and community celebratory and noncelebratory events in both private and public domains.

I conducted 'virtual' participant observation in family and community discussion forums on Facebook and Private Messenger during this time which also provided evidence of the use, context, and meanings of Pacific Island material culture that I discuss in this paper. 


\section{Salient links between diaspora and island homelands}

The significance of considering Pacific Island material culture within both the Auckland and Brisbane diaspora contexts is because several of the informants in the study lived in multi-diaspora contexts. These individuals moved freely between Auckland and Brisbane as Trans-Tasman migrants, and for some, in a circulatory movement between their Pacific homelands (Samoa/Tonga) and diaspora settings. Pacific Island material cultural adaptations used in diaspora contexts are an expression of identity, values, and beliefs as Samoan or Tongan people. In some instances, these expressions of identity are shared across different Pacific Island groups. Material culture adaptations are not confined to the contemporary settings of New Zealand or Australia, rather this has long been happening via historical connections and migratory processes between the peoples of Samoa and Tonga (Hau'ofa 1994). Neich (1985) documents the trade and exchange of material culture between Samoan and Tongan groups. Others like Sperlich (2006) argue that material culture from Samoa reveals the inter-cultural influences of other Pacific groups including Tongans. The contemporary material cultural adaptations observed in Auckland and Brisbane present values and beliefs originating from the Pacific homelands and carried to these diaspora contexts (cf. Abbott 2013).

For some diaspora, this process involved a redefining of cultural meanings within their contexts. Materials and templates were adapted and used freely in some instances, a point of creativity that is advocated by Van der Grijp (2011). In this discussion, 'templates' are the designs or patterns used to create material culture that have originated from either the homelands of Samoa or Tonga, and these same 'templates' continue to be the reference point for re-produced or re-defined materials within the diaspora contexts. An example of this is the use of a synthetic fabric in Auckland and Brisbane to make ngatu pepa (a hybrid bark cloth). My observations were similar to Addo $(2007,60)$ who has written about Tongan women using ngatu pepa in Auckland. However, the materials used by the informants in my more recent study have become more synthetic, even as their designs mimic original ngatu patterns from Tonga. These changes were a function of the lack of availability of island-sourced materials, so borrowed materials were often employed to create items that mimicked original templates. Material cultural adaptations are based on perceptions, attitudes, and worldviews (Mallon 2010; Memmott 2011). Although this discussion embraces the un-bound definition of culture and tradition that is advocated by Memmott (2011) and others (Sperlich 2006; Taouma 2002; Wendt 1976), we must be 
mindful that the internal thought processes of Pacific people are still bound to aspects of tradition that we value, regardless of our interactions with other cultures. Mallon $(2010,366)$ states that 'ultimately, tradition becomes a reality when people choose to act on it [...] it may be connected to actual past ideas or practices, it connects to them in a highly selective way'. Further to this, he claims that 'tradition' persists in many ways (Mallon 2010, 368). The evidence presented in this paper suggests that although there are aspects of material culture that have been redefined in diaspora contexts, there is a persistence of traditions from the island homelands. The Pacific Island worldview tends to be more collective than individualistic, which provides a reason for why the material cultural adaptations continue to embrace elements of shared traditions that are holistic.

\section{Pacific Island perspectives of a collective well-being}

Essentially, we Pacific Islanders see ourselves as a part of a whole. We are members of a greater collective that form along lines of kinship and genealogy, as well as other social and cultural connections (Ka'ili 2017, 52-55; Macpherson and Macpherson 2009, 73-77) between Pacific homelands and diaspora, including spiritual connections (Makasiale 2013, 277-278). As a result, Pacific Island social values and cultural elements have often been carried throughout a series of step-migration and transitory residences across diaspora settlements in New Zealand and Australia. Sociocultural values and elements inspire the spatial behaviour and material cultural adaptations used by Pacific Islanders in Auckland and Brisbane. Furthermore, material cultural adaptations and spatial behaviours reflect the holistic well-being perspectives held by Samoan and Tongan people. Addo (2017, 211-212, 215-217) acknowledges this in her study of Tongan koloa (material wealth) that is passed on across generations and across spaces between homelands and diaspora.

What surfaces in the research is the 'holistic' notion of Pacific Island well-being, as in mo'ui 'oku lelei (Tongan concept of a 'good and happy life'), and ola manuia (Samoan concept of a 'good and happy life'). These are significant concepts that inspire the spatial behaviours and cultural adaptations revealed within urban cultural spaces used by Pacific Islanders in Auckland and Brisbane. We view our well-being as more than tangible outcomes or improvements in the life of an individual. While the Tongan concept of mo'ui 'oku lelei and the Samoan one of ola manuia literally translate to the phrase 'a good and happy life', both these concepts embrace many dimensions of life that are integral to how we as Pacific Island people live daily (Faleolo 2016, 68). Pacific Islanders define well-being beyond just a state of physical or emotional health and include 
important familial and spiritual dimensions that connect individuals to their extended family networks (Gershon 2012), their village or church community (Ioane 2017; Ka'ili 2017; Lilomaiava-Doktor 2009), and further provide avenues for the continuation of cultural ways of living (Addo 2017; Hau'ofa 1994). The following two excerpts (from my research) reveal these shared holistic notions of Pacific Island well-being:

Sione, a second-generation Tongan (thirty-eight years) in transit between Auckland and Brisbane, who was based in a Perth mine, explains his understanding of mo'ui 'oku lelei: 'Being physically and mentally healthy $[\ldots]$ being able to have quality time and being content with [a] lifestyle that is healthy [...] happy with family life. Spending time with my family. Staying true to God and my family. Being able to spend my time doing what really matters to me. To be around to meet my grandchildren and to be able to retire from working full-time before I turn fifty' ${ }^{9}$

Ina, a second-generation Samoan (thirty-five years), who moved to Brisbane from Auckland in 2015, shared her understanding of ola manuia: 'having the simple necessities in life to at least be comfortable. Healthy family relationships, being well connected to family. Being physically healthy, able to still do physical activity to feel good, and eating well. Being spiritually healthy too, having that intimate relationship with God. Mentally stable too which I guess ties in with the other three. If one area is lacking, it can affect the other [areas]'.

\section{Spiritual well-being: God and church}

For many Pacific Islanders in Auckland and Brisbane, attending church is not only a spiritual experience but a social one where weekly church meetings and programs allow families and village members to connect and nurture their cultural way of living, based on a shared faith and a Christian values system. During field observations it was apparent that the adornment of the church meeting space reflected Pacific Island diaspora living out a sacrificial commitment to God. A pastor's wife explained that her finest kiekie (fine mat) was laid out on the floor area demarcated as 'the altar' (an area in front of the preacher's pulpit) and that her kiekie was more like a 'sacrifice to God of koloa (wealth)'. Whether the church meeting was held in an actual dedicated church building, a community hall, a converted carport, or hired classroom space, these spaces were usually decorated with material culture of the highest quality. The use of very expensive fine mats and traditional materials that would cost hundreds 
and sometimes thousands of dollars used as adornment in church settings in Auckland and Brisbane, is an indicator of the high significance that Pacific Islanders place on their spiritual well-being (Addo 2017, 212-219). Giving their best items and best efforts to the church, to the pastors or ministers, and to the functions and duties performed within the church meeting spaces, reflect what is important to Pacific Island migrants who attend churches within Auckland and Brisbane. 'Ofa Makasiale $(2013,277)$ advocates that 'spirituality $[\ldots]$ is a dynamic, guiding light in all aspects of life for the Pacific person' living in New Zealand. This is consistent with Pacific diaspora in USA who also prioritise their spirituality (Lilomaiava-Doktor 2009; Ka' ili 2017). Ihara and Ofahengaue Vakalahi $(2011,411-412)$ highlight spirituality as the essence of wellness among Samoan and Tongan elders in Pacific diaspora based in Hawai $i$, with a focus on the methods of connecting spiritually with God and with others through support networks in the church.

\section{Familial well-being: nuclear and extended families}

Pacific Island well-being and related behaviours can be better understood from the collective aspect of a Pacific Islander's worldview (Taumoefolau 2013). Auckland-based and Brisbane-based Pacific Islanders prioritise the family fämili/kāinga (Tongan) or 'äiga (Samoan). For many of the informants in the study, their references to family included the nuclear as well as extended as per the terms fämili and 'áiga. The progress of fämili and 'àiga are important considerations that sit at the core of Pacific Island decision-making. What is highlighted in the research is that well-being aims such as 'getting better pay' or 'better job opportunities', although seemingly individualistic, are means to providing for overall familial well-being and maintaining 'familial' connections that are very important to the well-being of Pacific Island people in Auckland and Brisbane.

\section{Material cultural adaptations in Auckland and Brisbane, 2015-2018}

In order to understand the significance of material cultural adaptations we must also consider the cultural underpinnings of the materials and templates used within the Auckland and Brisbane urban cultural landscapes that has influenced the material cultural adaptations within these diaspora contexts. The following is a list of the six variations of material culture discussed in the following sections:

1. Traditional materials used in traditional spaces with traditional meanings

2. Traditional materials used in adapted spaces with traditional meanings

3. Traditional materials used in adapted spaces with redefined meanings 
4. Adapted materials using traditional templates with traditional meanings

5. Adapted materials using adapted templates with traditional meanings

6. Adapted spaces using traditional templates with redefined meanings

1. TRADITIONAL MATERIALS USED IN TRADITIONAL SPACES, WITH TRADITIONAL MEANINGS.

Figure 1 shows the use of fine mats in a baby dedication in Auckland. The use of traditional Tongan attire and ta'ovala (a Tongan mat traditionally used as clothing, wrapped around the waist of both men and women) during this religious ceremony marks the significance of their child's life, and is worn in reverence of God in a place of worship. It is also an acknowledgement of their cultural heritage that has been given to them by their parents and is now being passed onto their child. Traditional spaces like the church provide avenues for Samoan and Tongan peoples to continue the use of traditional materials, like fine mats, while living in diaspora contexts.

Figure 2 shows the use of traditional materials in the costumes of Tongan dancers in Auckland. This event is a celebration of Tongan cultural heritage in

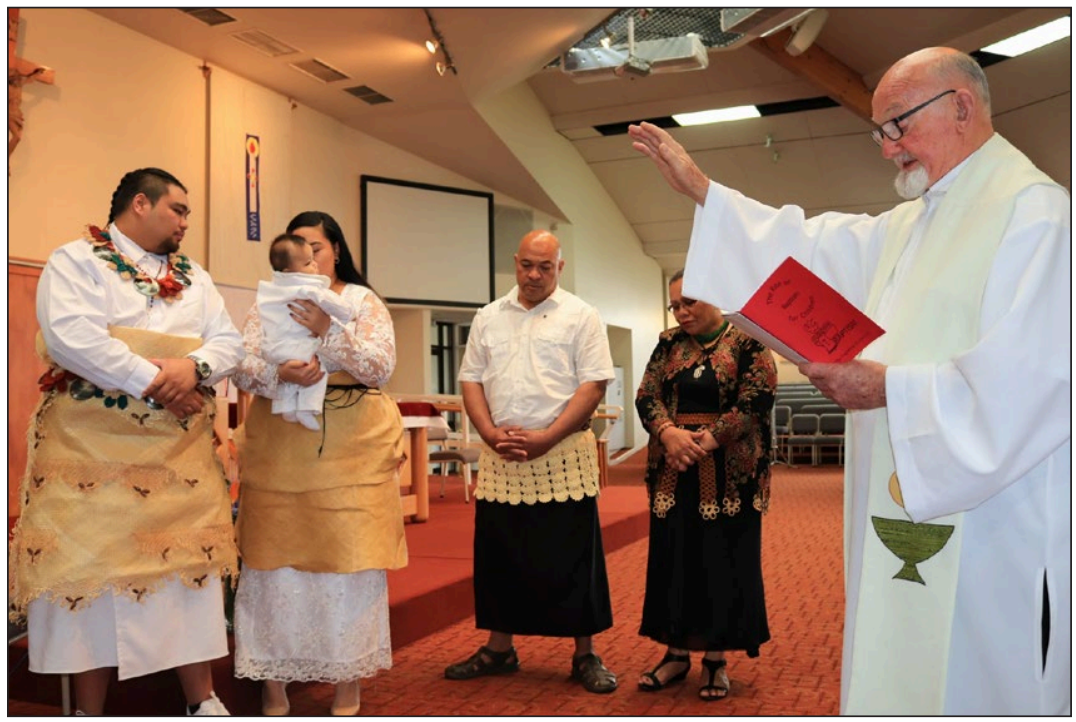

Figure 1. Religious ceremony, baby dedication in Auckland. Photographer: Rose Vainikolo Taumoeanga (19/11/2018). Used with permission. 


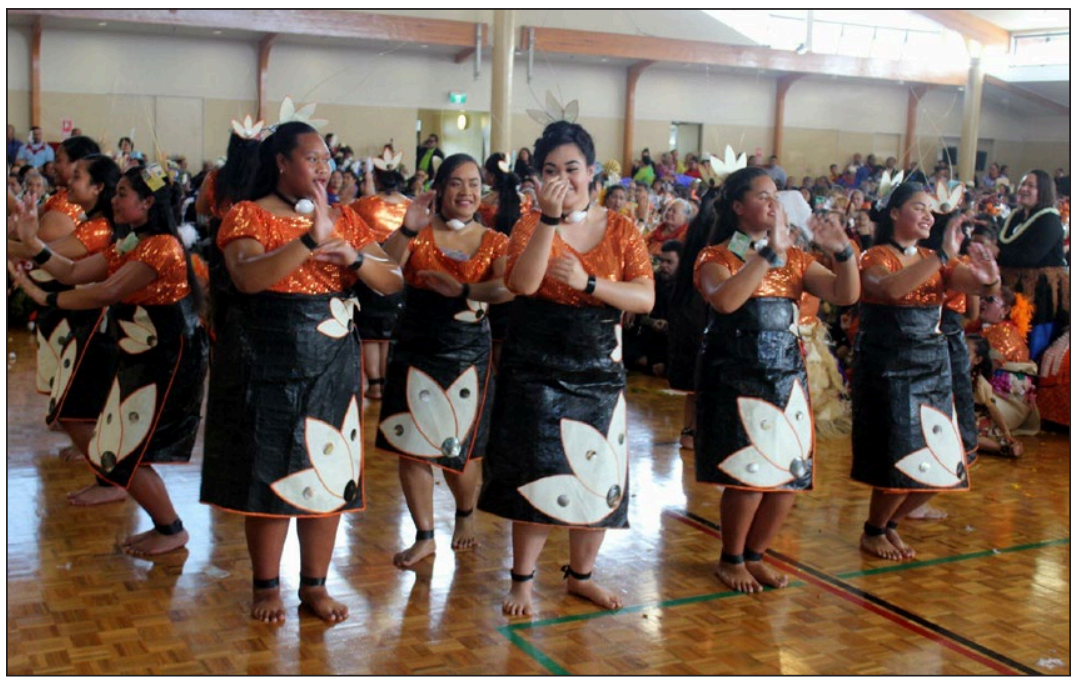

Figure 2. Tongan dance in Auckland community event. Photographer: Iunisi Paea (31/8/2018). Used with permission.

a community event that occurred in Auckland. The traditional materials (shells and ornaments) used in the embellishment of the ta'ovala worn by the dancers would have largely been supplied by family members commuting to and from Tonga over previous visits, and particularly by those family members visiting Auckland specifically to attend the event.

Figure 3 shows the use of fala (traditional Tongan mats commonly used on the floorspace for sitting on) and kie tonga (finely woven mat made from lou'akau, or pandanus leaves, in Tonga known as $\mathrm{kie}^{10}$ ) to decorate a multicultural Pacific Island church space in Brisbane. The use of fala and kie tonga, especially of this high quality, within the church demonstrates the reverence that members of this congregation have towards God. It is a traditional way of giving the best of their craft and wealth as a form of 'sacrifice to God'.

Figure 4 shows the traditional use of Samoan fine mats, in this context known as 'ie toga, in the costumes of Samoan dancers in Brisbane. One of the most significant roles in this traditional performance is carried out by the young woman wearing the impressive headpiece. She is known as the taupou (a female, traditionally a virgin, of importance) and presents a re-enactment of the Samoan siva taualuga (traditional celebratory dance at the completion of a community process). She is supported by a group of performers that are usu- 
ally in the background. This dance item was presented as the final part of this group's performance, signifying completion, as part of a city-wide secondary schools' cultural celebration in Brisbane.

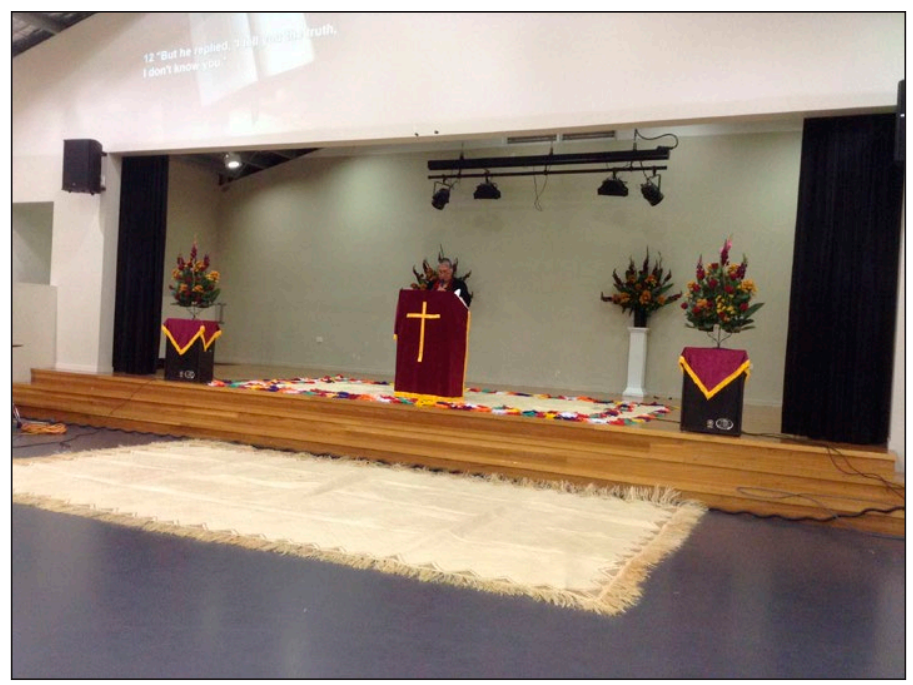

Figure 3. Fine mats used in decorating church space in Brisbane. Photographer: Author (5/7/2015). Used with permission.

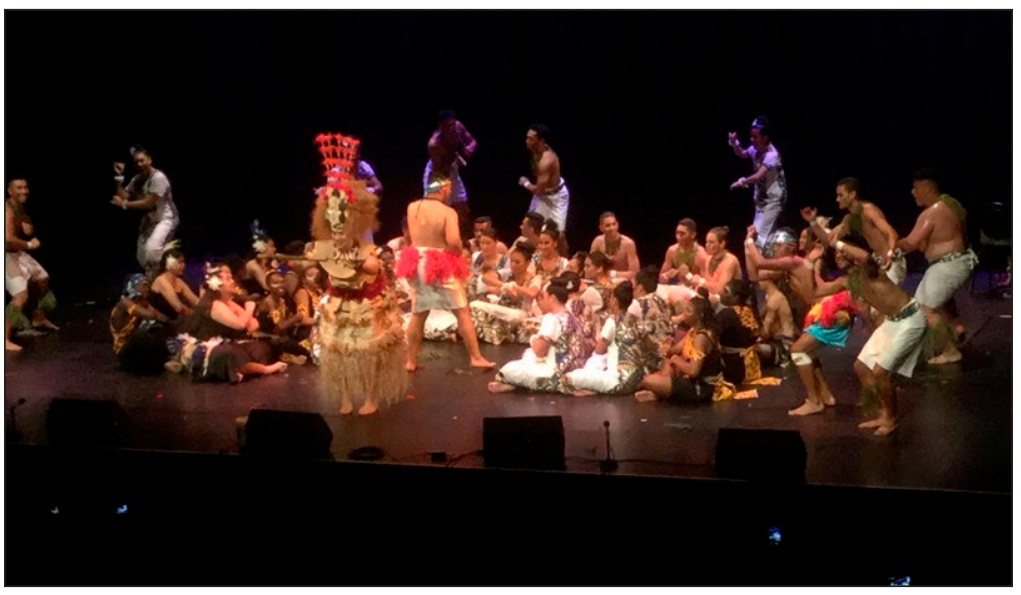

Figure 4. Samoan dancers wear traditional attire in Brisbane. Photographer: Author (7/10/2017). Used with permission. 
As shown in the images presented above, the continued use of Samoan and Tongan material culture within diaspora contexts is evident in traditional spaces used for church or dance performances. Highly valued items like fine mats are presented or worn within these spaces to signify the importance of the event, the place or the presence of God, and people of significance. Cultural meanings and value systems are continued with the use of traditional material culture in these traditional spaces.

\section{TRADITIONAL MATERIALS USED IN ADAPTED SPACES, WITH}

TRADITIONAL MEANINGS.

Figure 5 shows the use of traditional ngatu (decorated bark-cloth made from the paper mulberry tree) and fine mats in an adapted space used for an academic ceremony in Auckland. It is traditional in the Pacific Islands to celebrate achievement with the gifting and adornment of traditional fine mats and bark-cloth (Tongans call this bark-cloth ngatu while the same type of textile is known to Samoans as siapo), as this is a way of edifying both the event and

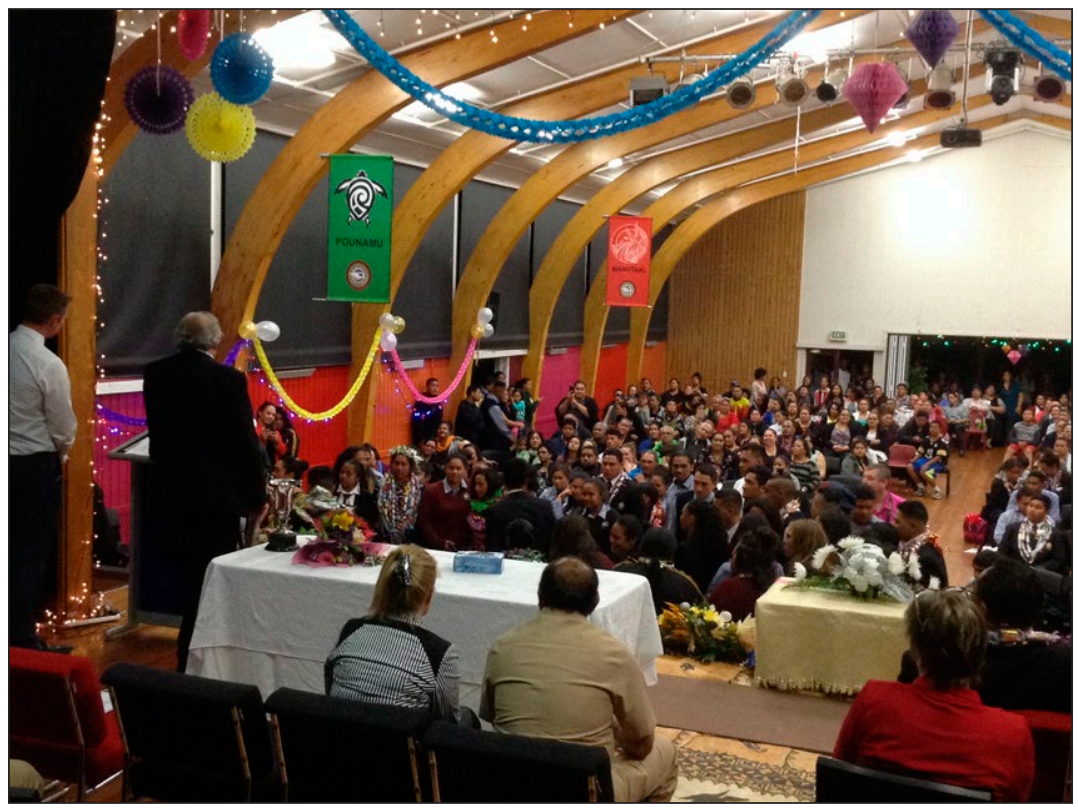

Figure 5. Photograph of prizegiving event using traditional materials as decorative and symbolic elements in an Auckland school hall. Photographer: Author (5/11/2015). Used with permission. 
those attending the event. The use of traditional materials is not only decorative but representative of the cultural values pertaining to the Pacific Island cultures (including Cook Islanders, Fijian, Niuean, Maori, Samoan, Tongan and Tokelauan) represented at the end-of-year prizegiving event shown here. The display of ngatu (laid on the stage) and kie tonga (covering the side table) were donated by Tongan members of staff at the school to decorate the school hall for this special occasion.

Figure 6 shows the use of traditional ta'ovala at a university graduation in Auckland. The Tongan graduate and her grandfather are wearing ta'ovala to mark the special occasion of her attainment of a tertiary qualification. The use of traditional attire during academic celebrations in tertiary spaces is a common practice amongst Pacific Island graduates and their families, including Samoan and Tongan academics. This act of respect is in acknowledgement of both their families' support and their Pacific indigeneity, thereby connecting to their island homelands within their diaspora contexts. Also, the adornment of bodies with these valuable materials elevates the event, in other words, adapts the nontraditional space into a culturally meaningful space even, if just temporarily.

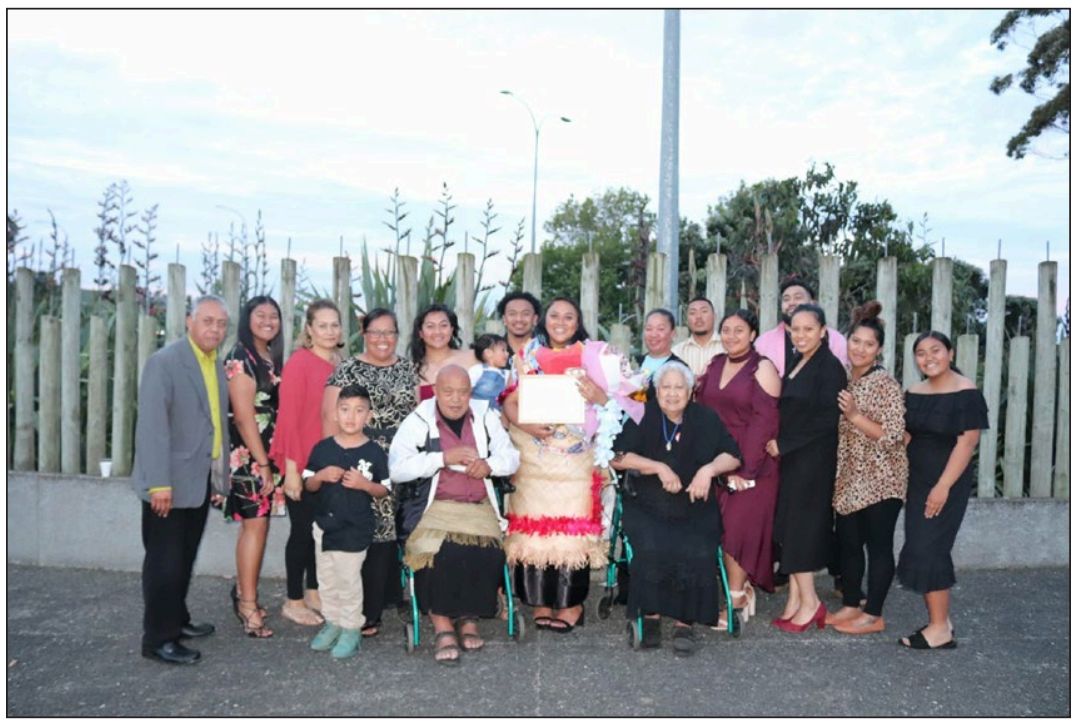

Figure 6. Photograph of Tongan academic graduating from a tertiary institute based in Auckland. Photographer: Rose Vainikolo Taumoeanga (24/11/2018). Used with permission. 
As observed by Addo (2017), there is a spiritual significance attached to koloa in Auckland by Tongan women who collect kie and ngatu which is eventually passed onto the next generation of daughters and granddaughters as heirlooms. A Brisbane-based informant in my study shared how her Auckland-based mother had brought a fine mat to Australia for her to wear on her graduation day. She remembers that it was the same fine mat that she had worn for her wedding a few years earlier. It was a special mat because her grandmother had made it in Tonga, and it has since been used in New Zealand and Australia for many important events. Hence, traditional material culture of high sociocultural value is transferred across space (homelands and diaspora) and time (generations). Traditional materials carried from the island homelands into diaspora contexts are highly valued, often because of who made it, how it was made, where it originates from and the purpose for which it was made. These aspects all add to the sociocultural value of the material culture used to elevate events in diaspora contexts.

Figure 7 shows the traditional use of kie tonga and cultural adornments in the teunga (traditional Tongan dance costume) worn by dancers at an adapted space, during a collaborative performance by Tongan community members and the local brass band in Brisbane. A Tongan traditional tauolunga is performed by five female dancers, supported by community members, both non-Tongan

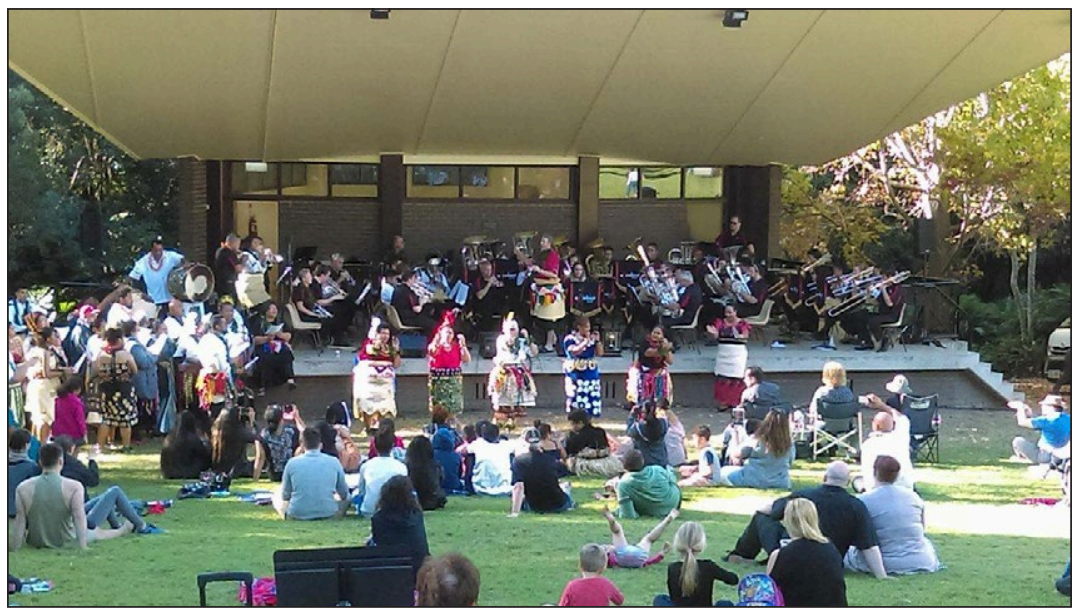

Figure 7. Photograph of Tongan community performance in collaboration with community brass band in Brisbane. Photographer: Dr. Charmaine 'Ilaiū Talei (3/6/2017). Used with permission. 
and Tongan members of the community singing and playing as part of the brass band. This was an outdoor event, held at a Logan council park, celebrating community. The use of traditional materials and dance remains both celebratory and representative of Tongan cultural values, although adapted to the local community and space provided by the council. The meanings of these performances remain intact using materials, lyrics, and dance actions that have been carried on through the generations and taught by cultural leaders in diaspora communities.

Figure 8 shows the traditional use of a mat in an adapted space used for a church service. This church gathering takes place on a weekend and uses the local school for their services. The classroom space shown in the image has been adapted for church use and the addition of a traditional mat provides a cultural furnishing of the space as well as conveying dignity to the temporal place of worship. During my observations in both Auckland and Brisbane, I came across several church groups using community halls, schools, and business spaces for their weekend services. This is a common practice amongst church groups in Pacific diaspora contexts while they fundraise for their own

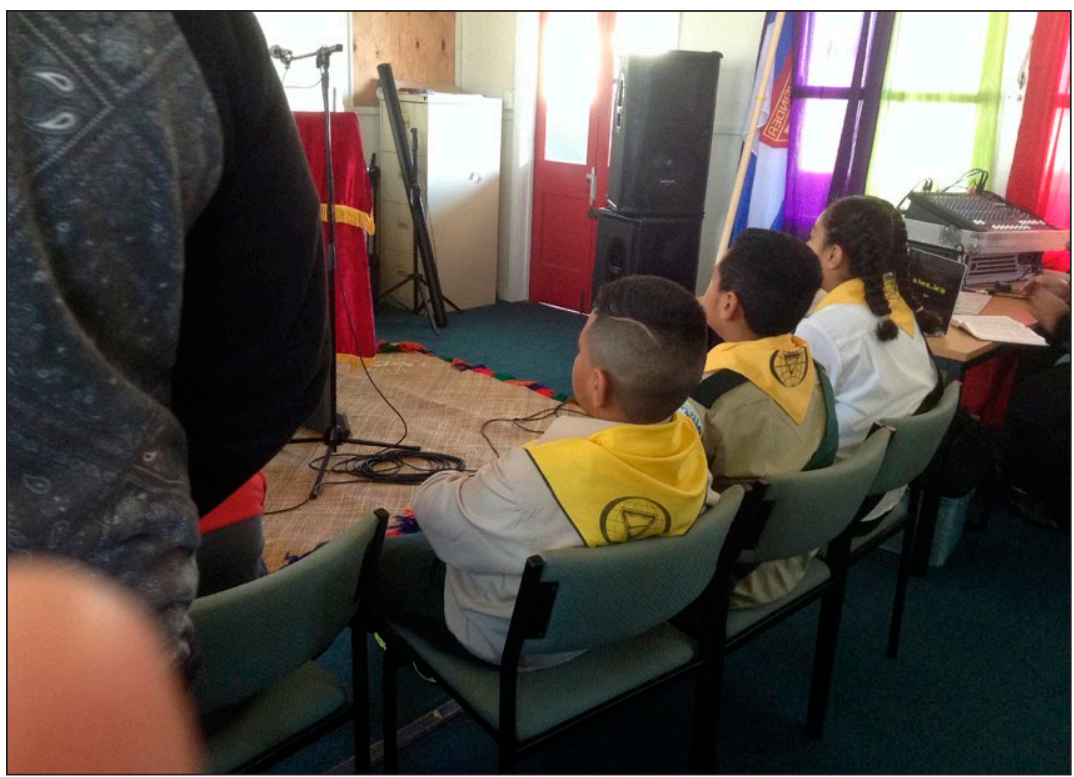

Figure 8. Photograph of Tongan church meeting space in an adapted school classroom in a Brisbane school. Photographer: Author (18/7/2015). Used with permission. 
dedicated places of worship. This is both a benefit to the local councils, schools, and businesses who maintain an extra income through hiring their spaces that would otherwise be unused during these times, and benefits community church groups that need temporal, flexible, and affordable spaces for their growing congregations.

The images above have shown the continued use of Samoan and Tongan material culture within adapted spaces (such as local parks, school buildings, and universities) that provide these groups with temporal spaces to continue sharing their culture and traditions. According to many of my informants, the significance of this spatial behaviour within Auckland and Brisbane is the ability to pass on their cultural wealth, values, and knowledge to the next generation.

\section{TRADITIONAL MATERIALS USED IN ADAPTED SPACES, WITH REDEFINED} MEANINGS.

Figure 9 shows a kupesi (design printed and drawn onto ngatu) that has been framed as an art piece and sold at a pop-up stall at the annual Pasifika event in Auckland in 2016. This is an example of the use of traditional materials within adapted spaces and with redefined meanings. This kupesi design has been outlined with kafa (rope made from niu, coconut coir fibres) and laid onto a backdrop of ngatu. The kupesi is traditionally used by Tongan women in the ngatu-making process; its imprint creates a constant pattern across great lengths of tapa when dye is rubbed onto the surface of ngatu laid over the kupesi. The kupesi in this image has been repurposed into a piece of framed artwork that was sold to tourists and spectators attending the Pasifika event. Kupesi carry traditional motifs and designs that Tongan women share time and time again through the act of making ngatu. The meaning of kupesi has been redefined by the artist as it is now framed as a wall display, an elaboration of its original use as a collective design tool.

Figure 10 shows Tongan youth wearing traditional ta'ovala, kafa, and vala tupenu (skirt-style wrap-around clothing worn by both Tongan women and men) with their western-style trends of footwear and clothing items. During my observations in Auckland, this combination of both traditional and western attire was common amongst both Samoan and Tongan youth. This shows a pride and respect for culture amongst Samoan and Tongan youth, who take ownership of re-defining their own sense of style and fashion, as Pacific Islanders living in a diaspora context. During observations in schools in South Auckland (Auckland, New Zealand) and Logan (Brisbane, Australia), some Samoan and Tongan male students chose to wear their tupenu as part of their 


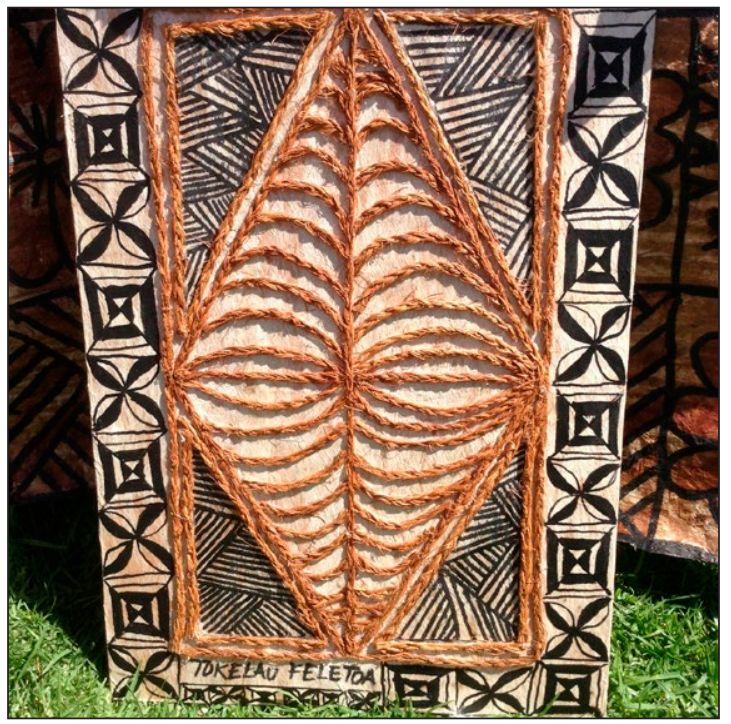

Figure 9. Photograph of a pop-up stall selling kupesi design framed as artwork in Auckland cultural event. Photographer: Author (12/3/2016). Used with permission.

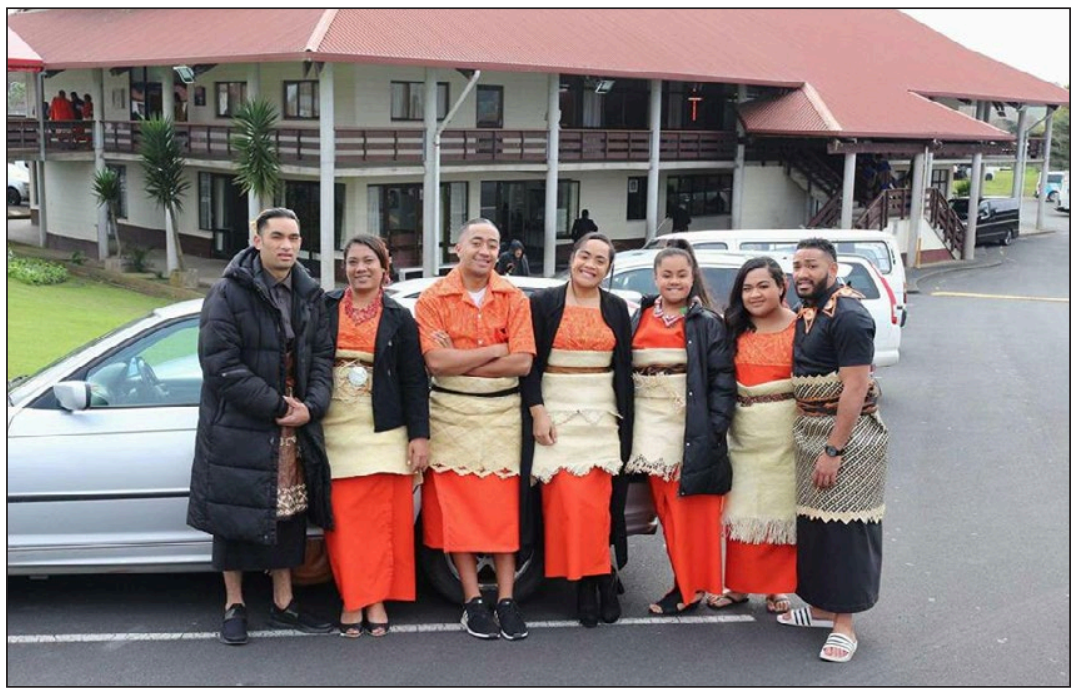

Figure 10. Photograph of Tongan community members representing their village in Auckland-based event. Photographer: Iunisi Paea (2/9/2018). Used with permission. 
formal school uniform. Likewise, Māhina-Tuai $(2012,164)$ shares an image of a Wesley College (Auckland) student's adaptation of the Tongan ta'ovala and tupenu as part of their school formal dress uniform in 1996.

Figure 11 shows the use of traditional 'ie toga in a city council space, above the entrance to the local library of the Logan Central area in Brisbane that is densely populated with Pacific Islanders. The use of this traditional and rather large 'ie toga shows both an acknowledgement of the Pacific Island peoples in this area, as well as respect for the traditional landowners by those who had gifted the precious mat. This 'ie toga originates from Samoa and is a public display of the collective culture shared by Samoans in the Brisbane diaspora.

Figure 12 shows the use of Tongan fine mats known as kie ha'amoa and ngatu in a baby shower event that was celebrated by both Samoan and Tongan family members of the mother-to-be. A significant observation made at this event was the intermingling of Samoan, Tongan, and Western ideas in the re-thinking

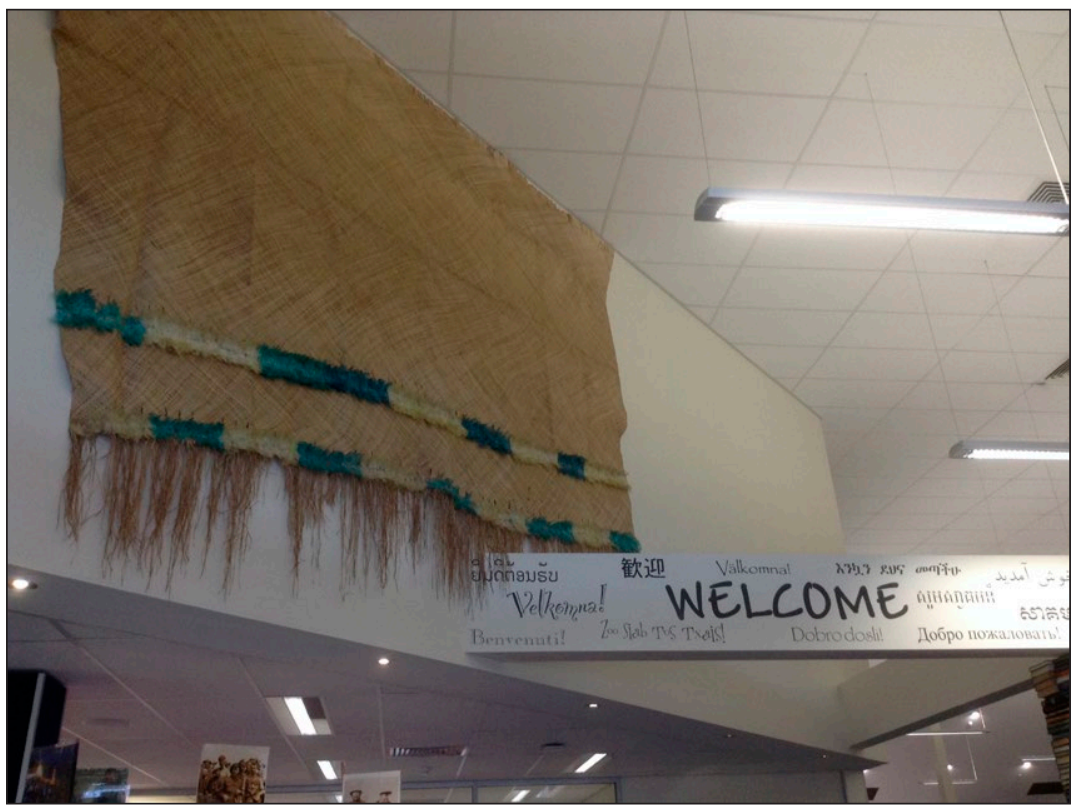

Figure 11. Photograph of Samoan 'ie toga displayed above entry to a public, council owned, library in Logan, Brisbane. Photographer: Author (14/4/2015).

Used with permission. 
around what a baby shower ought to be. It was discussed by the older women attending the event that it was unusual practice for them personally, to celebrate a baby's imminent arrival. They compared this new celebration to their traditions of visiting a mother and her new-born to welcome a baby after its birth. This unique use of traditional material culture, in a reinvented event using a converted backyard space, demonstrates how culture is evolving with Pacific Islanders living in diaspora contexts.

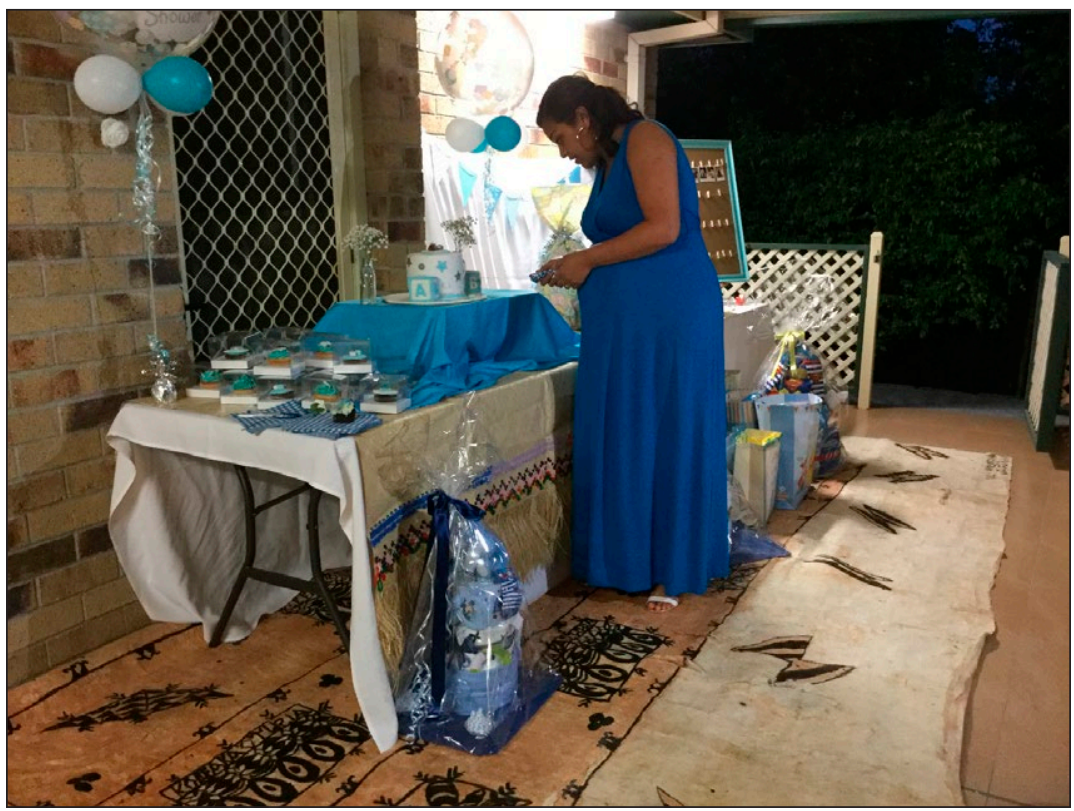

Figure 12. Photograph of a display using ngatu and kie tonga at a baby shower in Brisbane. Photographer: Tessalina Faraimo (16/4/2016). Used with permission.

These images have shown the continued use of Samoan and Tongan material culture within adapted spaces, public and private, that have allowed for the redefining of meanings and items used in these adapted spaces.

\section{ADAPTED MATERIALS USING TRADITIONAL TEMPLATES WITH}

TRADITIONAL MEANINGS

Figure 13 shows the use of adapted materials like aluminium foil in the preparation and cooking of a traditional Tongan dish that is prepared and eaten 
on a regular basis by this family, as observed in Auckland. This dish is $l \bar{u}$ pulu masima (taro leaves with salted beef) and contains an ample amount of coconut cream, which in Auckland, will usually be tinned. Traditionally, this dish is made in Tonga with the same ingredients. However, the coconut cream is freshly squeezed, the dish is wrapped in banana leaves, not foil, and then cooked in an ' $u m u$ or earth oven. Tongans based in Tonga are slowly increasing their use of foil, although the use of banana leaves is seen as more economically sustainable and better for one's health. However, in Auckland, it is now common practice to make traditional meals using more convenient methods of cooking like foil-wrapped $l \bar{u}$ in the conventional oven. Whilst the traditions of using an ' $u m u$ are still practiced by Auckland and Brisbane diaspora, these are reserved for significant events like weddings, birthdays, or funerals. In both diaspora and Pacific homeland contexts, the use of foil and conventional ovens are considered signs of fakalakalaka, a Tongan concept referring to modernity and progressive changes that improve overall areas of living ('Ilaiū 1997, 82; 'Ilaiū-Talei 2014, 37).

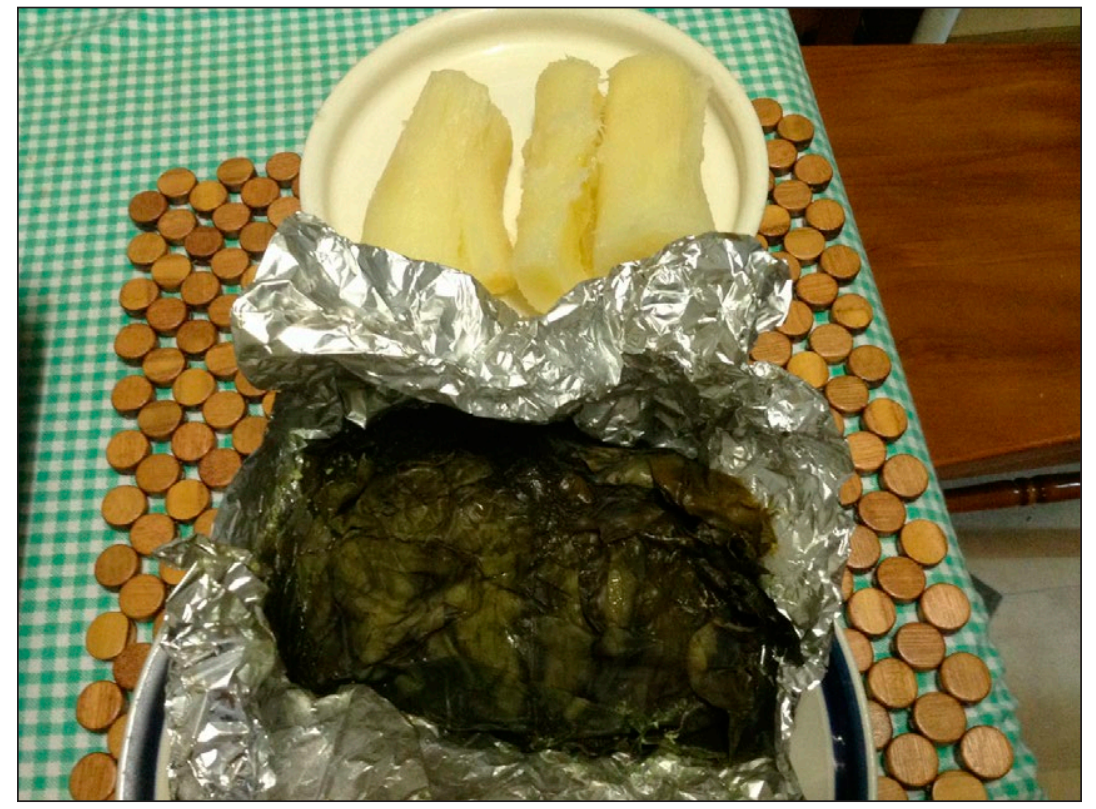

Figure 13. Photograph of lü pulu masima served with manioke in a Tongan home in Auckland. Photographer: Author (11/3/2016). Used with permission. 
Figure 14 shows the use of locally purchased materials in the creation of teunga for Tongan dancers in Auckland. This is evidence of the use of adapted materials to maintain the practice of cultural arts from Samoa and Tonga. The kiekie worn by the women in this image have been created using polypropylene curling ribbons purchased from a local discount store. The plastic material is easy to work, available in assorted colours, and allows the creation of traditional looking teunga in less time (no traditional planting, harvesting of materials, and preparation required). The popularity of this type of kiekie worn in diaspora contexts relates to the convenience of accessing materials locally and the low cost of purchasing these materials. However, the use of different materials in the creation of kiekie does not remove the significance of wearing one while performing. Women wear kiekie as a sign of cultural respect. The use of kiekie allows further participation of Tongan youth in the celebration of their culture in community events like this, Pasifika 2016, which is an annual event hosted by the Auckland City Council.

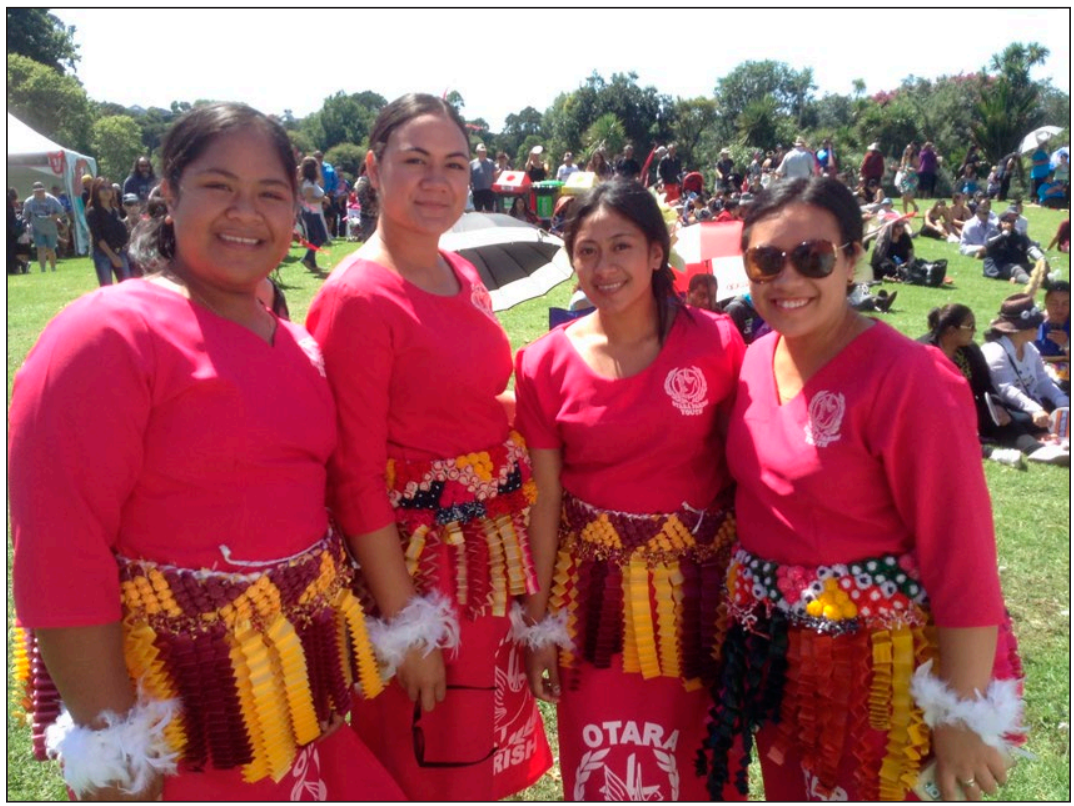

Figure 14. Photograph of Tongan performers at a city council-sponsored event in Auckland celebrating the cultures of the Pacific nations represented in their city's population. Photographer: Author (12/3/2016). Used with permission. 
Figure 15 shows the use of adapted materials, in the preparation of traditional foods, using traditional templates and maintaining traditional meanings. This Tongan woman in the photograph was preparing a traditional Tongan dish of $l \bar{u}$ sipi (taro leaves with mutton), using taro leaves wrapped around a filling of meat, diced vegetable, and coconut cream. The dish was cooked in a conventional oven for a couple of hours. It was prepared especially by this Aunty for an extended family member's birthday celebration that was held later that day. Traditional preparation of this dish would have entailed an ' $u m u$ that would have taken a little longer to prepare and cook. Despite the adapted materials used, the preparation and cooking of this family meal retains traditional meanings of tauhi $v \bar{a}$ (maintaining relationships) with service based on 'ofa (love).

Figure 16 shows the use of adapted materials in the creation of Tongan dance costumes, used by both Tongan and non-Tongan students at a Brisbane school cultural celebration. Non-traditional materials were used to reduce the cost of making traditional costumes and because they were readily available to

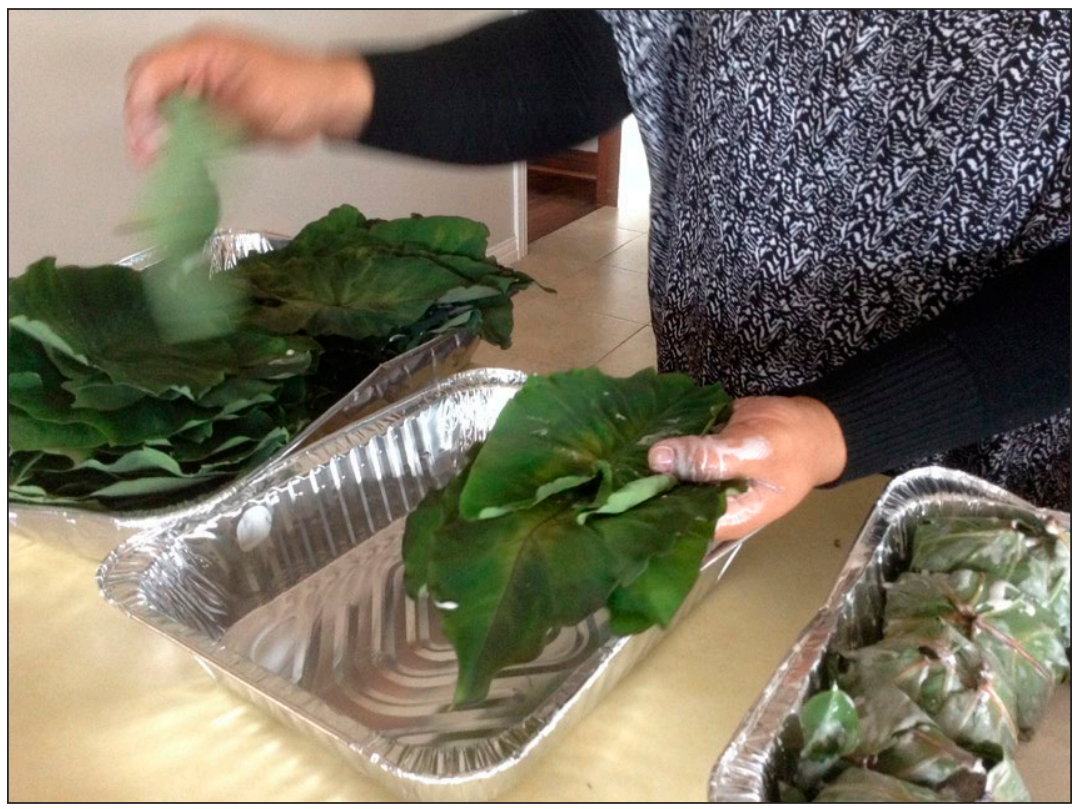

Figure 15. Photograph showing the use of foil trays in preparing a traditional Tongan dish of $l \bar{u}$ sipi, in a Tongan/Māori family home in Brisbane. Photographer: Author $(11 / 7 / 2015)$. Used with permission. 
members of this school cultural group (including Tongans, Samoans, Māori and South African students and their parents) based in Brisbane. The ta'ovala was created by Samoan and Tongan staff and student volunteers from black weed-mat and tied with braided polypropylene rope, replacing the traditional materials of lou'akau and niu that were not available in bulk to these students and their families. Accessories like the tekiteki (feathered head stick), vesa (wristlets and anklets made from stringed feathers), and the kahoa tau'olunga (ribbon-tied necklace used for dance) were also created by Samoan and Tongan student volunteers using less traditional materials purchased from a local Chinese shop. These included satin ribbons, dyed ostrich feathers, and acrylic rhinestones which combined, created a look that mimicked the traditional designs of traditionally crafted teunga from Tonga. The off-shoulder style of the white tops were requested by the students because it was fashionable at the time in Brisbane and was created by one of the student's mother using a pattern drawn by a Samoan-Tongan artist ${ }^{11}$ based in Brisbane. The overall design of the teunga used by this school cultural performance has maintained the cultural values attributed to the Tongan tauolunga.

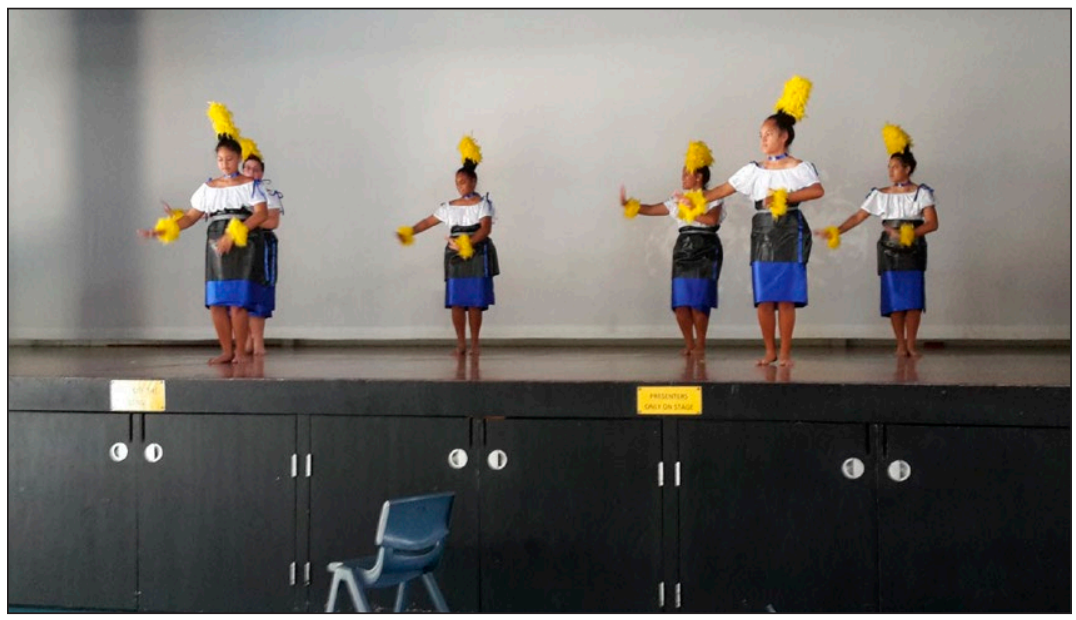

Figure 16. Photograph showing non-Tongan and Tongan students performing a Tongan tauolunga in teunga (dance costume) made extensively from adapted materials in Brisbane. Photographer: Author (20/3/2018). Used with permission. 
5. ADAPTED MATERIALS USING ADAPTED TEMPLATES, WITH TRADITIONAL MEANINGS.

Figure 17 shows the use of adapted materials: shop-bought confectioneries and Australian-dollar bills were used to create the kahoa lole (lolly necklace) and kahoa pa'anga (money necklace) worn by two high school graduates in Brisbane. These items were gifted by family members and friends to the students who were celebrating the end of their formal education at year twelve. In Auckland, I had observed on the rare occasion the use of fragrant flowers and foliage (when available) for high school graduations, but the kahoa lole was more commonly used. Most rare was the kahoa pa'anga with New Zealand dollar bills. Samoan informants refer to kahoa lole as 'ula lole (lolly necklace). 'Ula lole or kahoa lole are commonly worn during special occasions like graduations, birthdays, Mothers' Day, Fathers' Day, or Children's Day (White Sunday) celebrations. The 'ula lole or kahoa lole is placed on the person who is celebrating their milestone or achievement by relatives or friends. It is important to note that the practice of endowing a person during celebrations with 'ula lole or kahoa lole, or even kahoa pa'anga is becoming more acceptable across other Pacific Islands groups ${ }^{12}$

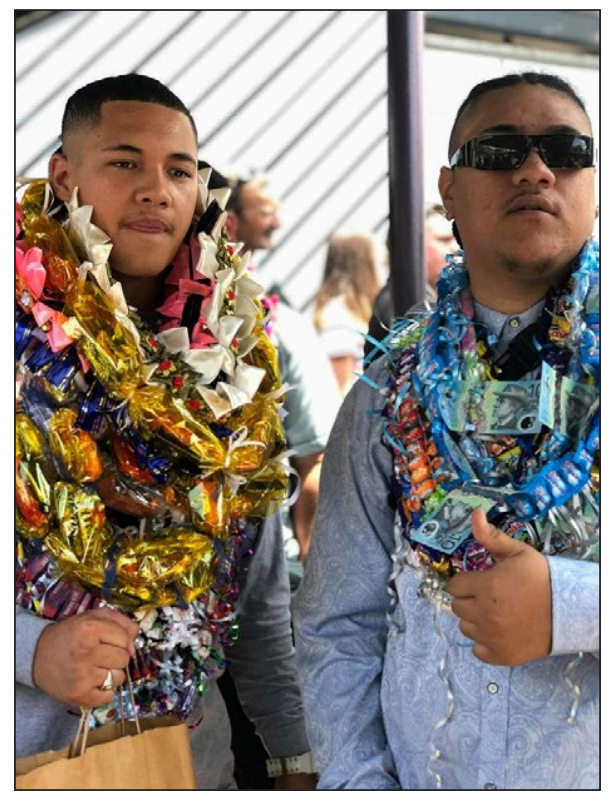

Figure 17. Photograph of two Pacific Islander high school graduates in Brisbane.

Photographer: Robyn Finau (17/11/2018). Used with permission. 
in New Zealand (as observed at a Cook Islands Māori 21st birthday celebration in Auckland). This is evidence of the continued act of reciprocity and giftgiving originating from the Pacific homelands, that continues between family members and extended members living in diaspora communities. Although the materials and the templates are adapted to suit the contexts of Auckland and Brisbane, the act of gift-giving continues the cultural values of love and respect that nurture relationships - tauhi $v \bar{a}$ and teu le $v \bar{a}$ - within diaspora contexts.

Figure 18 shows a Tongan graduate with her parents, holding a floral arrangement that had been prepared by the local florist, as well as a lei made from fabric and plastic materials. This is an example of the use of adapted materials and templates with traditional meanings. Such items, although not traditional, continue the traditional act of gifting floral kahoa (necklace or lei) to a top scholar at an academic event in Tonga. Like the previous image, this photo also shows evidence of modified materials in the making of kahoa, with an assortment of kahoa lole. Families and friends of the graduate will have prepared these kahoa lole days before the graduation ceremony and presented the kahoa to her as a way of showing their love and respect for the graduate, and as an acknowledgement of the sacrifices she and her family have made to

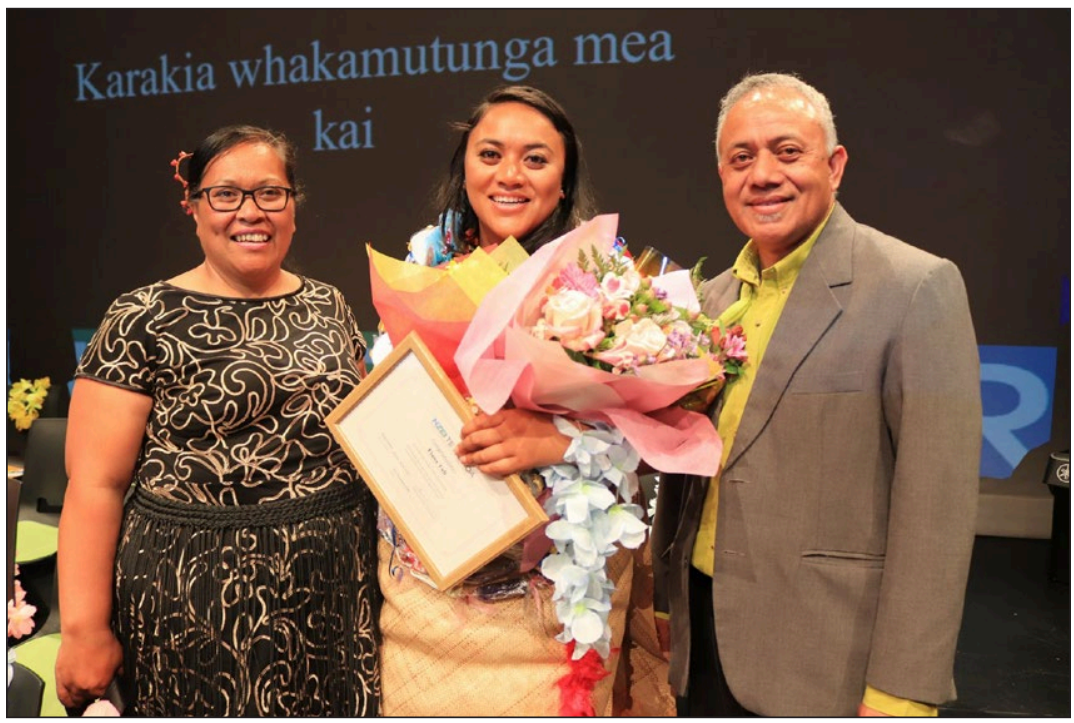

Figure 18. Photograph of Tongan graduate with parents, holding flower arrangement and synthetic flower lei, in Auckland. Photographer: Rose Vainikolo Taumoeanga (24/11/2018). Used with permission. 
gain her qualification. The successful attainment of academic degrees is seen as a fakalakalaka fakalukufua or a collective and progressive act for the whole family (Faleolo 2012, 55-56). In many instances, the first member of the family or collective to achieve a certain qualification is acknowledged and celebrated by the village and island homeland, diaspora included.

Figure 19 shows the use of tatau (tattoo) designs in a community poster that promotes a Pacific Island rugby league event in Brisbane. This demonstrates the pan-Pacific identity via adapted templates, and solidarity through traditional meanings that Pacific diaspora communities share in the Brisbane context. The cultural designs used here are unifying symbols accepted across several groups affiliated with the Pacific region and homelands. Such events like the rugby league and cultural celebration days promote solidarity and shared cultural pride amongst diaspora Pacific Islanders in Brisbane. The adaptation of material culture within diaspora contexts is not a loss of culture, rather an enrichment of cultural values and meanings that are often shared across several Pacific groups.

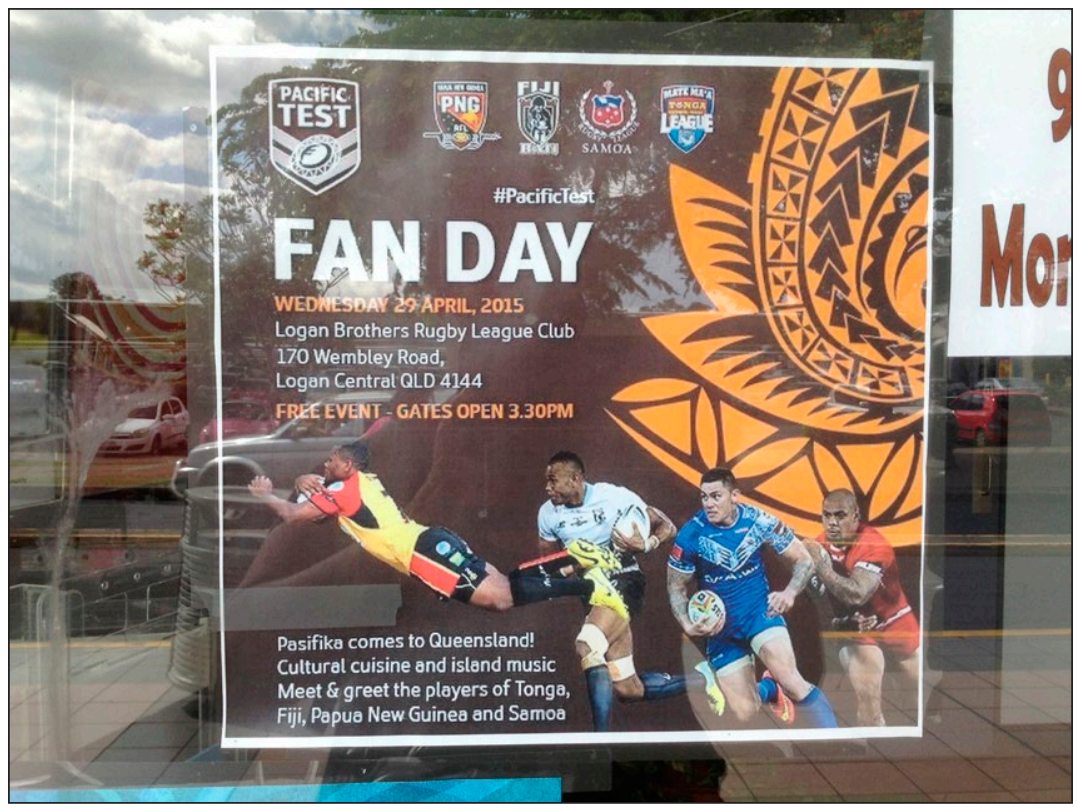

Figure 19. Photograph showing Pacific Island designs used in a community poster, promoting a Pacific Island sport event, in Logan, Brisbane. Photographer: Author (14/4/2015). Used with permission. 
Figure 20 shows the continued act of reciprocity and the traditional meanings of this between Auckland and Brisbane diaspora through the gifting of local specialties using adapted materials. This image shows a favoured type of biscuit for Auckland-based people which is highly prized in New Zealand diaspora because of its distinct flavour. It is a commonly available product in Coles franchise supermarkets in Australia. This biscuit is usually purchased and packed as luggage in Australia, then gifted on arrival to family members in Auckland. This package was delivered to family members who had personally requested the biscuits online via Facebook posts on hearing that a family member would be travelling across the Tasman. This form of material cultural adaptation is based on the reciprocity and cultural gifting that takes place between family members travelling between New Zealand and island homelands, usually with the exchange of more traditional foodstuffs in the ' $u m u$ pack'13 or crafts made in Samoa/Tonga.

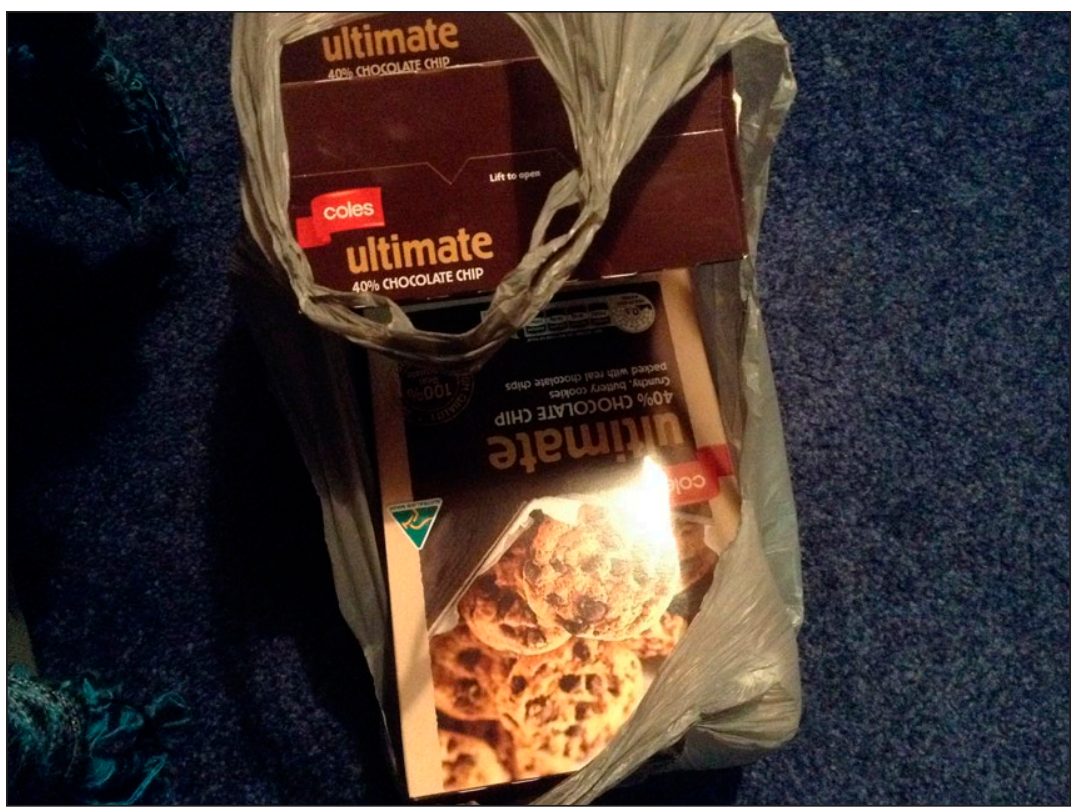

Figure 20. Photograph showing the use of Australian-bought goods, parcelled and gifted by Trans-Tasman migrants from Brisbane to Auckland. Photographer: Author (11/3/2016). Used with permission. 

MEANINGS.

Figure 21 shows the use of an adapted space in a Tongan/Samoan family home in Auckland. The importance of shared or common areas, amongst Tongan fämili/käinga or Samoan 'äiga (traditional template), is evident in this conversion (adapted space). This garage space had been converted into an extra living area where family gather for special events (such as birthdays, funerals, or prayer meetings). The extra rooms to the side of this shared open space provided further living quarters for this family. During my observations in both Auckland and Brisbane, it was common to see both Samoan and Tongan families using their garage spaces as extended living areas. This common practice of converting garage or carport spaces allows larger families to provide extra room for their members. This practice also allows a family to support extended family members, usually newlyweds or recently migrated families needing a place to stay temporarily while they are saving for their own place to settle. Providing shared living spaces in the home is a traditional template

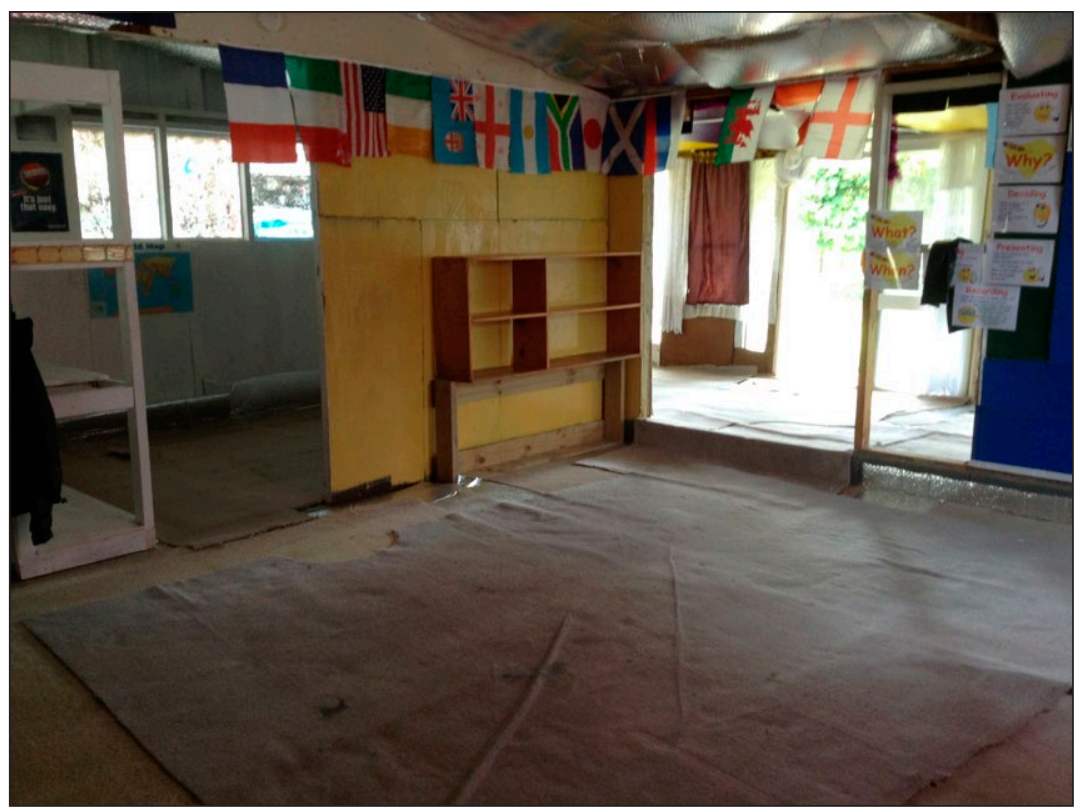

Figure 21. Photograph showing a common practice, of converting garage spaces for shared family living areas, in Auckland. Photographer: Author (7/12/2015). Used with permission. 
of living that is brought from the island homeland. This collective way of living often requires additional open-plan or shared spaces as it is a cultural way of living as prescribed by fa'a-Sämoa or anga faka-Tonga.

Figure 22 shows the Samoan stage at the Pasifika annual event in Auckland in 2016. This adapted space is usually maintained for a variety of football games, like soccer and touch rugby. However, for the week leading up to the Pasifika event, and during it, there was a hive of activity involving both businesses and community groups in preparing the site. This open area was converted to a performance stage to cater for the expected attendance of Samoan and nonSamoan alike during the cultural celebration. Although the event is a commercialised form of cultural display, there are positive outcomes for those involved in the dances, speeches, crafts stalls and food stalls. Younger generations of Samoans can maintain strong cultural connections through their involvement in this annual event; the visible concentration of Samoans in this space, each year, provides Samoan diaspora with a sense of pride and a reason to maintain their unique cultural knowledge and skills.

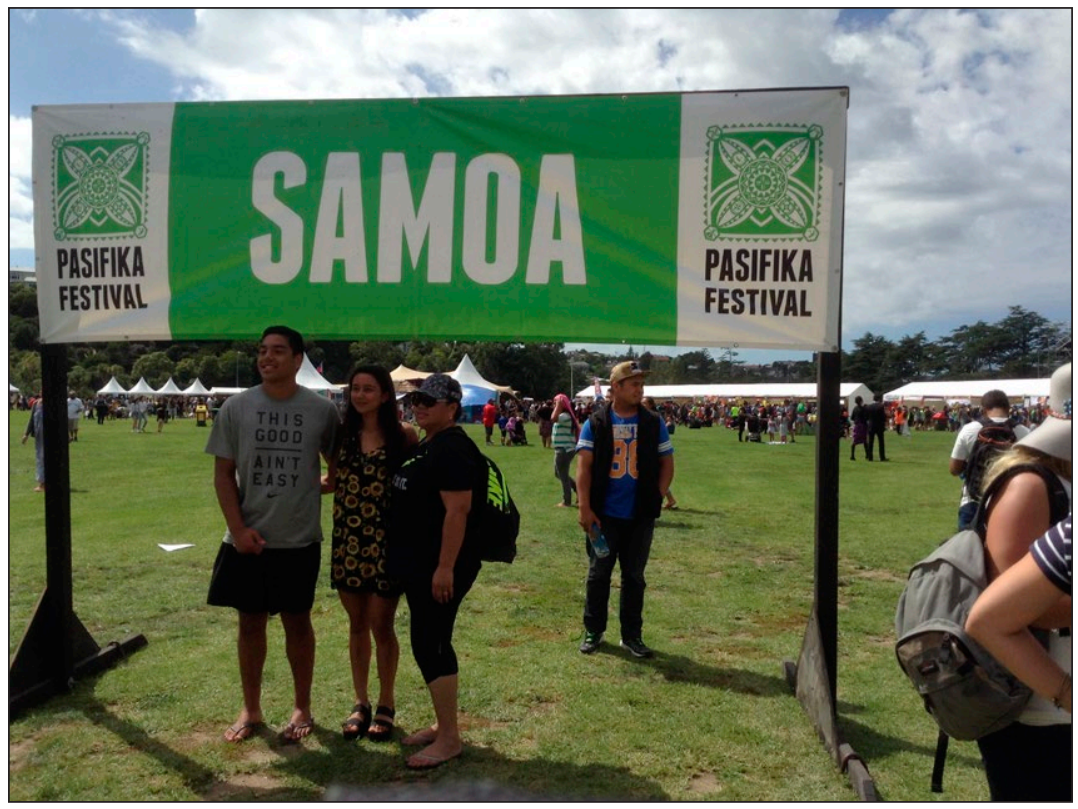

Figure 22. Photograph showing the adapted use of a public sport field, for cultural celebrations in Auckland. Photographer: Author (12/3/2016). Used with permission. 
Figure 23 shows the adapted double garage used as a shared living area in a Samoan/Tongan family home in Brisbane. The purpose of this conversion was to accommodate eleven members from the äiga/käinga/fämili who were visiting, during the Christmas holidays from Auckland and Sydney. It made sense for the owners of this home to convert the garage into a shared living space that would continue to be of use in the future during extended family gatherings and events. Their intentions reveal the continued use of traditional templates that reference the Pacific homelands for shared accommodation and collective living in diaspora contexts. The image also shows the use of polypropylene mats instead of the traditional mats. The mats were brought across from New Zealand by the visiting family members, who were able to purchase these at a low cost and carry them as luggage. Compared to traditional mats, these polypropylene mats are lightweight and easily compacted. The use of mats on the floor provides the family with flexible spaces and plenty of room to sit and sleep. Traditional templates based on tauhi $v \bar{a}$ or teu le $v \bar{a}$ (maintaining good sociospatial relationships) inspires the conversion of homes, particularly garage spaces. In Auckland and Brisbane, homes designed for nuclear families have been re-defined by the collective way of living.

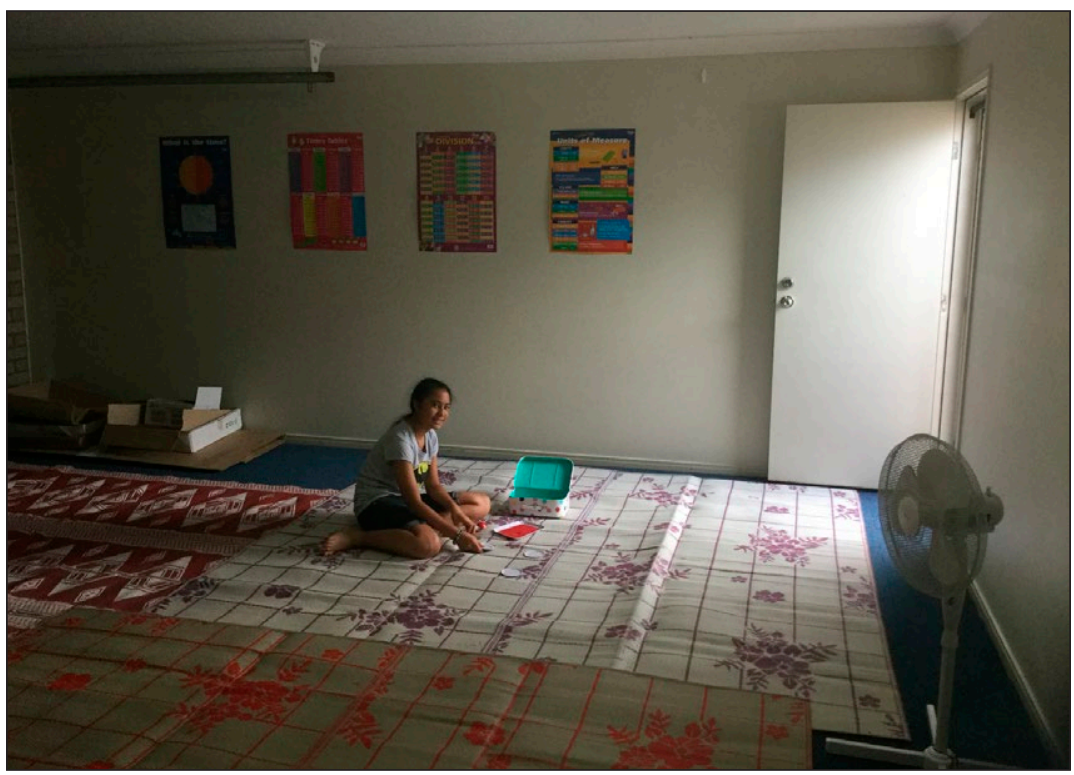

Figure 23. Photograph showing a common practice, of converting garage spaces for shared family living areas, in Brisbane. Photographer: Author (25/12/2016).

Used with permission. 
Figure 24 shows the use of an adapted space, a foyer area outside a church building in Brisbane, which is being used for a cultural performance and the distribution of cultural foods. This traditional siva is performed by Samoan women wearing two-piece outfits known as pule-tasi. The design of pule-tasi is traditional but has been adapted using materials available in Brisbane. The family members supporting their dance, including the younger children, are wearing yellow lei; these le $i$ are made from fabric and polypropylene materials, available from the local discount store. Although some diaspora spaces and materials are non-traditional, the templates that they are based on remain true to $f a^{\prime} a-S a m m o a$ protocols of dance and collective family identity.

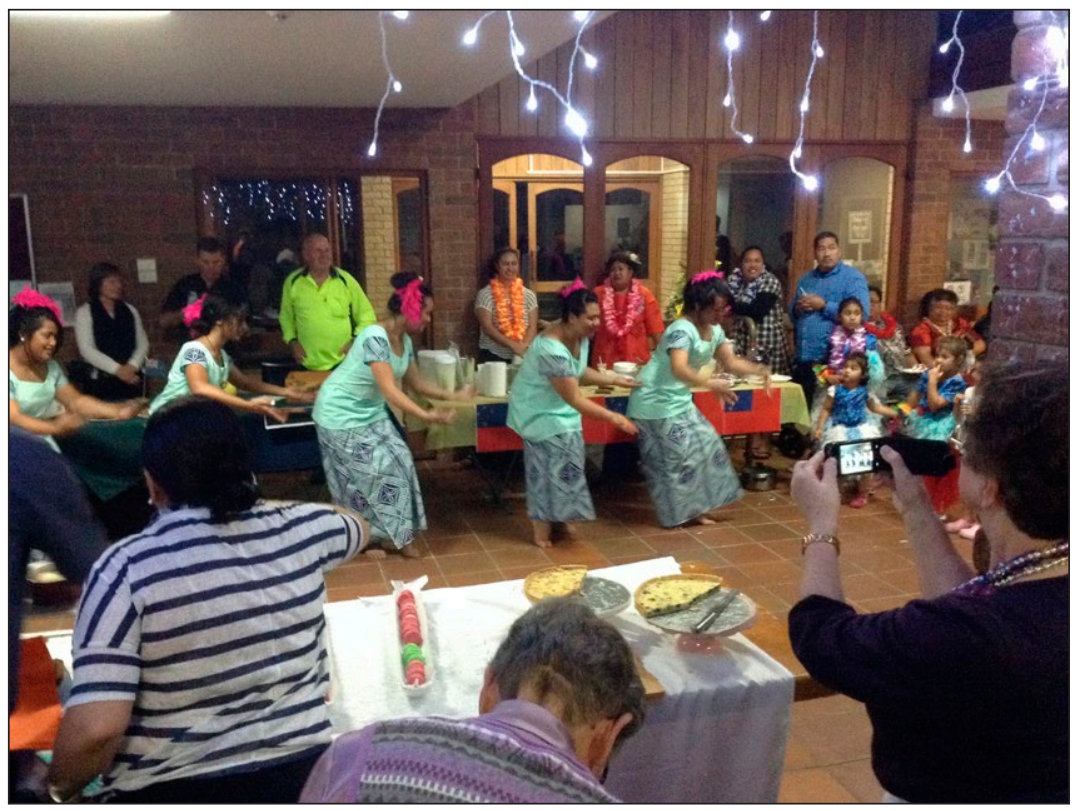

Figure 24. Photograph showing the adapted use of a covered foyer area, and entry to a church building in Brisbane, for the purpose of a cultural celebratory event organised by church members. Photographer: Author (5/9/2015). Used with permission.

\section{CONCLUDING REMARKS}

Pacific Island material culture used in diaspora contexts reveals cultural resilience. As Samoan and Tongan migrants expand further from their Pacific homelands, we continue to use traditional materials, templates, and meanings from Samoa and Tonga. Our traditions and culture are ever present when 
adapted materials, adapted spaces, and redefined meanings are used in diaspora contexts. This is a continued expression of the identity, values, and beliefs of Samoan and Tongan people. The shared spatial behaviours within observed diaspora communities reflect the desire to maintain traditions alongside an improved well-being in Auckland and Brisbane. Therefore, Pacific material culture in Auckland and Brisbane reveals continued connections between Pacific homelands and diaspora, founded on anga faka-Tonga and fa'a-Sämoa.

\section{ACKNOWLEDGMENTS}

'Oku ou tōmu'a tuku a e fakafeta'i kihe 'Eiki; ke langilangi'ia pe ia! Fakamālo atu kihe 'eku 'ofa'anga: Thom, Israel, Sh'Kinah, Nehemiah, Lydiah mo Naomi Faleolo. Fakamālo atu kihe'eku ongo mātu'a, Faifekau 'Ahoia mo Faifekau Lose 'Ilaiū. Fakamālo lahi atu kihe kāinga Tonga mo 'äiga Samoa kotoape na'e tokoni'i eku fekumi.

I acknowledge all informants in Auckland and Brisbane who contributed valuable narratives to this paper, including images provided by Tessalina Faraimo, Robyn Finau, Dr. Charmaine 'Ilaiū Talei, Iunisi Paea and Rose Vainikolo Taumoeanga. I also acknowledge Prof. Paul Memmott and Dr. Kelly Greenop of the Aboriginal Environments Research Centre, as well as Prof. Mark Western and Dr. Denise Clague of the Institute for Social Science Research at the University of Queensland (UQ). Funding from the UQ School of Architecture, UQ Graduate School and Life Course Centre, Brisbane, has supported my research during 2016-2019.

NOTES

1 Ruth (Lute) Faleolo is a PhD candidate with the Aboriginal Environments Research Centre, and Institute for Social Science Research, at the University of Queensland. Ruth's PhD research focuses on the well-being of Pasifika TransTasman migrants, of Samoan and Tongan descent, in Auckland and Brisbane.

Email: ruth.faleolo@uqconnect.edu.au

2 This is like the Chinese Canadian 'double diaspora' movements (Guo 2016, 153154).

3 'Áiga is a Samoan term that can be used to refer to the community family within relevant social contexts that an individual or family feels strongly connected to or engaged in, e.g. school, church, village, online global community etc. 
4 Käinga is a Tongan term that is used to refer to the extended family or community within a social context, e.g. school, church, village, online global community etc.

5 Fämili is a Tongan term that is used widely to refer to family; a reference to family circle that is usually inclusive of nuclear and extended family groups.

6 Forty initial interviews were conducted in 2015. These initial interviews led to follow-up interviews in 2015-2018. At the start of the interviews in 2015, most informants were already living in Brisbane with the remaining interviews conducted with informants who were planning to move. By 2016, five of the Auckland-based informants and one based in-transit from Perth, were in Brisbane. Another two informants moved from Auckland to Brisbane in 2018.

7 E-talanoa is discussed in-depth in a separate paper by the same author (Faleolo, forthcoming). Working title: 'Indigenous Knowledge Cultivated Through ETalanoa'.

8 I have termed this email 'volley' to describe the 'to-and-fro' pattern of conversation that was happening over the internet during the e-talanoa sessions that would often take several days between questions and answers, responses and feedback. Note that during both emails and private messenger conversations, as well as during face-to-face talanoa, the informant would ask me (researcher) questions that I would then respond to in order to continue the dialogue. I was always open to allowing informants to ask questions of me in accordance with the concept of talanoa. Informants were given the control during part of the conversation in order to create a $v \bar{a}$ (relational social space between two or more people) of mutual respect and understanding. Often their questions were asked in order to find out more about me as the researcher or to double-check that I had understood them. This 'to-and-fro' and 'volley' process of e-talanoa facilitated a more in-depth dialogue between my informants and me.

9 At the time of writing this paper, and after follow-up talanoa with Sione, he told me that he and his family had successfully migrated to Brisbane after purchasing a family home. Sione continues to fly out to the mines and is making plans to leave this form of employment in exchange for a family business based in Brisbane.

10 Author unknown. 2019 'Made in Tonga', para.10. < http://www.madeintonga. com/products/c/82/Weaving $>$ accessed 22/04/2019.

11 Sh'Kinah Tuia'Ana Nauna Faleolo is the author's daughter, a New Zealand-born, 
third generation Pasifika Trans-Tasman migrant, of Samoan and Tongan descent, based in Brisbane at the time.

12 I observed that the intercultural exchanges in Auckland's multicultural setting have allowed for a merging and borrowing of cultural knowledge in ways that are quite unique to the Auckland context.

13 The 'umu pack' is a box containing island foodstuffs (taro, yams, etc.) that have been cooked (usually in an earth oven) and prepared by family members in the island village and sent to the families in the diaspora with a member of the extended family that is travelling there.

\section{REFERENCES}

Abbott, Rachel G. 2013. The Scandinavian Immigrant Experience in Utah, 1850-1920: Using Material Culture to Interpret Cultural Adaptation. PhD Dissertation, University of Alaska Fairbanks.

Addo, Ping-Ann. 2007. 'Commoner Tongan Women Authenticate Ngatu Pepa in Auckland'. Pacific Arts: New Series 3-5: 60-73.

- 2015. 'Tongan Women and Migratory Circuits of Wealth and Value(s)'. Migration, Mobility, and Displacement 1(1):99-111.

- 2017. 'Passing On, and Passing on Wealth: Compelling Values in Tongan Exchange'. In Sinuous Objects: Revaluing Women's Wealth in the Contemporary Pacific, edited by Anna-Karina Hermkens and Kathy Lepani, 211-234. Canberra: ANU Press.

Barcham, Manuhuia, Regina Scheyvens, and John Overton. 2009. 'New Polynesian Triangle: Rethinking Polynesian Migration and Development in the Pacific'. Asia Pacific Viewpoint 5o (3):322-337.

Bedford, Richard. 2007. Pasifika Mobility: Pathways, Circuits and Challenges in the 21st Century. Hamilton: University of Waikato Population Studies Centre.
- 2009. 'Pasifika Migration: The New Zealand Story'. Around the Globe $6(1): 37-44$.

Brettell, Caroline. 2003. Anthropology and Migration. Walnut Creek, CA: Altamira Press. 
Enari, Dion. 2019. 'Fa'a Saymore - From Promised Land to Dream Land: Perceptions of Fa'a Samoa by New Zealand Born Samoans in Brisbane, Australia'. Anthropology Working Papers Seminar Series, University of Queensland, Brisbane. Accessed 30 July 2019 from https://social-science.uq.edu.au/event/ session/3745

Fa'avae, David, Alison Jones, and Linitā Manu'atu. 2016. 'Talanoa'i 'a e Talanoa: Talking About Talanoa'. AlterNative 12 (2):138-150.

Faleolo, Ruth. 2012. Higher Education in New Zealand: A Form of Fakalakalaka for Educated Tongan Women? MEd Thesis, Massey University.

- 2016. 'Pasifika Trans-Tasman Migrant Perspectives of Well-Being in Australia and New Zealand'. Pacific Asia Inquiry 7 (1): 63-74.

- 2019. 'Wellbeing Perspectives, Conceptualisations of Work and Labour Mobility Experiences of Pasifika Trans-Tasman Migrants in Brisbane'. In Labour Lines and Colonial Power: Indigenous and Pacific Islander Labour Mobility in Australia, edited by Victoria Stead and Jon Altman, 185-206. Canberra: ANU Press.

Gershon, Ilana. 2007. 'Viewing Diasporas from the Pacific: What Pacific Ethnographies Offer Pacific Diaspora Studies'. The Contemporary Pacific 19:474-504.

-2012. No Family is an Island: Cultural Expertise Among Samoans in Diaspora. New York: Cornell University Press.

Green, Alison E., Mary R. Power, and Deannah M. Jang. 20o8. 'Trans-Tasman Migration: New Zealanders' Explanations for their Move'. New Zealand Geographer 64:34-45.

Guo, Shibao. 2016. 'From International Migration to Transnational Diaspora: Theorizing "Double Diaspora” from the Experience of Chinese Canadians in Beijing'. International Migration and Integration 17:153-171.

Halapua, Sitiveni. 2007. 'Talanoa - Talking from the Heart'. SGI Quarterly 47: 9-10.

Hau'ofa, Epeli. 1994. We Are the Ocean. Honolulu: University of Hawai'i Press.

Ihara, Emily S. and Halaevalu F. Ofahengaue Vakalahi. 2011. 'Spirituality: The Essence of Wellness Among Tongan and Samoan Elders'. Journal of Religion 
and Spirituality in Social Work: Social Thought 30 (4):405-421.

Havea, Jione. (Ed.). 2010. Talanoa ripples: Across borders, cultures, disciplines. Albany, New Zealand: Massey University Pasifika@Massey.

'Ilaiū, Ruth. 1997. Signs of Development as 'Fakalakalaka' in Tonga? A Consideration of the Views and Changing Roles of Tongan Women. Master of Arts Dissertation, University of Auckland.

'Ilaiū Talei, Charmaine. 2014. 'Understanding How the Tongan Idea of Fakalakalaka Relates to the Western Idea of Sustainable Design When Building Houses in Tonga. The Journal of Pacific Studies 34 (2):37-52.

Ioane, Julia. 2017. 'Talanoa with Pasifika Youth and their Families'. New Zealand Journal of Psychology 46 (3):38-45.

Ka'ili, Tevita O. 2017. Marking Indigeneity: The Tongan Art of Sociospatial Relations. Arizona: The University of Arizona Press.

Lilomaiava-Doktor, Sa iliemanu. 2009. 'Beyond "Migration": Samoan Population Movement (Malaga) and the Geography of Social Space (Vā)'. The Contemporary Pacific 21 (1):1-32.

Macpherson, Cluny and La'avasa Macpherson. 2009. The Warm Winds of Change: Globalisation in Contemporary Samoa. Auckland, New Zealand: Auckland University Press.

Mafi, Siaosi F. 2018. Ko e Talanoa Fekau'aki Pea Moe Mo'ui Kakato ó e Mātu'a Tonga Nofo Nu'usila: The Perspectives of Wellbeing of Older Tongan People Living in New Zealand: A Qualitative Study. Master of Health Care Thesis, Victoria University of Wellington.

Māhina-Tuai, Kolokesa. 2012. 'A Land of Milk and Honey? Education and Employment Migration Schemes in the Post War Era'. In Tangata O Le Moana: New Zealand and the People of the Pacific, edited by Sean Mallon, Kolokesa Māhina-Tuai, and Damon Salesa, 161-178. Wellington: Te Papa Press.

Mallon, Sean. 2010. 'Against Tradition'. The Contemporary Pacific 22 (2):362-381.

Memmott, Paul. 2011. 'Cultural Change and Tradition in the Indigenous Architecture of Oceania'. Architectural Theory Review 16 (1):38-54. 
Mila-Schaaf, Karlo. 2010. Polycultural Capital and the Pasifika Second Generation: Negotiating Identities in Diasporic Spaces. PhD Thesis, Massey University.

Neich, Roger and National Museum of New Zealand. 1985. Material Culture of Western Samoa: Persistence and Change. Wellington: National Museum of New Zealand.

Otsuka, Setsuo. 2006. 'Talanoa Research: Culturally Appropriate Research Design in Fiji'. In Proceedings of the Australian Association for Research in Education (AARE) 2005 International Education Research Conference, Melbourne. Accessed 11 July 2010 from http://www.aare.edu.au/o5pap/otso5506.pdf

Park, Kye-Young. 1997. The Korean American Dream: Immigrants and Small Business in New York City. Ithaca, NY: Cornell University Press.

Poot, Jacques. 2010. 'Trans-Tasman Migration, Transnationalism and Economic Development in Australasia'. Asian and Pacific Migration Journal 19 (3):319342.

Pope, Sonia T. 2017. The Intergenerational Views of Wellbeing Amongst Tongan Women in New Zealand. Master of Arts Thesis, University of Auckland.

Portes, Alejandro and Rubén G. Rumbaut. 2001. Legacies: The Story of the Immigrant Second Generation. Berkeley: University of California Press.

Prescott, Semisi M. 2008. 'Using Talanoa in Pacific Business Research in New Zealand Experience with Tongan Entrepreneurs'. AlterNative: An International Journal of Indigenous Peoples 4 (1):127-148.

Pye, David 1999. 'The Six Requirement for Design'. In Material Culture Studies in America, edited by Thomas J. Schlereth, 153-161. Lanham: AltaMira Press.

Schlereth, Thomas J. 2001. 'Domestic Life and Material Culture'. In International Encyclopedia of the Social and Behavioural Sciences, edited by Neil J. Smelser and Paul B. Baltes, 3826-3830. Amsterdam: Elsevier Ltd.

Scull, Charles A. 2004. Identity Configurations: Re-inventing Samoan Youth Identities in Urban California. PhD dissertation, University of Southern California.

Singleton, Royce A. and Bruce C. Straits. 2010. Approaches to Social Research. NY: Oxford University Press. 
Sperlich, Tobias. 2006. 'Embodied Inter-cultural Dialogues: The Biography of a Samoan Necklace in Cologne'. Journal of the Polynesian Society 115 (2):119-144.

Taouma, Lisa. 2002. 'Getting Jiggy With It: The Evolving of Pasifika Dance in New Zealand'. In Pacific Art Niu Sila: The Pacific Dimension of Contemporary New Zealand Arts, edited by Sean Mallon and Pandora F. Pereira, 133-145. Wellington: Te Papa Press.

Taumoefolau, Melenaite. 2013. 'Respect, Solidarity and Resilience in Pacific World Views: A Counselling Perspective'. In Pacific Identities and Well-being: CrossCultural Perspectives, edited by Margaret N. Agee, Tracey McIntosh, Philip Culbertson, and Cabrini 'Ofa Makasiale, 131-145. Wellington: Otago University Press.

Thomsen, Su'a, with Jez Tavita and Zsontell Levi-Teu. 2018. A Pacific Perspective on the Living Standards Framework and Wellbeing. Discussion Paper 18/og presented to New Zealand Treasury, Wellington, August 2018. Accessed 3 February 2019 from https://treasury.govt.nz/sites/default/files/2018-08/dp18-09.pdf

Va'a, Leulu F. 2001. Saili Matagi: Samoan Migrants in Australia. Suva: Institute of Pacific Studies, University of the South Pacific and Iunivesite Aoao o Samoa, National University of Samoa.

Vaioleti, Timote M. 2006. 'Talanoa Research Methodology: A Developing Position on Pacific Research'. Waikato Journal of Education 12:21-34.

- 2016. 'Talanoa: A Tongan Research Methodology and Method'. In Encyclopedia of Educational Philosophy and Theory, edited by Michael A. Peters, 1-9. Singapore: Springer Nature Singapore Pte Ltd.

Van der Grijp, Paul. 2011. 'Contemporary Tongan Artists and the Reshaping of Oceanic Identity'. In Changing Contexts, Shifting Meaning: Transformations of Cultural Traditions in Oceania, edited by Elfriede Hermann, 277-295. Honolulu: University of Hawai'i Press.

Wendt, Albert. 1976. 'Towards a New Oceania'. Mana Review 1(1):49-6o. 